\title{
Experimental Study on Static Load of Large-Diameter Piles in Nonuniform Gravel Soil
}

\author{
Baoyun Zhao $\left(\mathbb{D},{ }^{1,2,3}\right.$ Xiaoping Wang, ${ }^{1,2}$ Mijia Yang, ${ }^{4}$ Dongyan Liu, ${ }^{1,2}$ DongSheng Liu, ${ }^{5}$ \\ and Shuguo Sun ${ }^{5}$ \\ ${ }^{1}$ School of Civil Engineering and Architecture, Chongqing University of Science and Technology, Chongqing 401331, China \\ ${ }^{2}$ Chongqing Key Laboratory of Energy Engineering Mechanics \& Disaster Prevention and Mitigation, Chongqing 401331, China \\ ${ }^{3}$ Key Laboratory of Well Stability and Fluid \& Rock Mechanics in Oil and Gas Reservoir of Shaanxi Province, \\ Xi'an Shiyou University, Xi'an 710065, China \\ ${ }^{4}$ Department of Civil and Environmental Engineering, North Dakota State University, Fargo 58108-6050, ND, USA \\ ${ }^{5}$ Chongqing Bureau of Geology and Minerals Exploration, Chongqing 401121, China
}

Correspondence should be addressed to Baoyun Zhao; baoyun666@163.com

Received 7 December 2019; Revised 28 May 2020; Accepted 9 June 2020; Published 11 July 2020

Academic Editor: Pier Paolo Rossi

Copyright ( 92020 Baoyun Zhao et al. This is an open access article distributed under the Creative Commons Attribution License, which permits unrestricted use, distribution, and reproduction in any medium, provided the original work is properly cited.

With the development of tourism, the number of multistorey buildings in mountain areas is increasing gradually, and the requirements of the form and bearing capacity of foundation in landslide areas are getting more demanding than ever. In-situ testing of rock and soil mass in slope area has important practical significance for improving the stability of building foundation. Taking a project in Baishi Mountain located in southwest of China as an example, firstly, the geological structure and mechanical properties of soil are analyzed. Then, two types of pile foundations, i.e., empty-bottom pile foundations and solid-bottom pile foundations, are designed based on the characteristics of the geological structure for carrying out the static load test on pile foundation. The test results are as follows: (a) the load settlement curve (Q-S) of the empty-bottom test pile shows a steep drop, while the Q-S curve of the solidbottom test pile shows a gradual change, showing that the end-bearing friction pile's property and the ultimate bearing capacity of the solid-bottom pile are higher than those of the empty-bottom pile. (b) The maximum lateral friction of the four test piles is $139.158 \mathrm{kPa}, 148.015 \mathrm{kPa}, 150.828 \mathrm{kPa}$, and $154.956 \mathrm{kPa}$, respectively. (c) The shaft skin resistance under ultimate load is coming close to the maximum value, and the maximum values are $9.792 \mathrm{~mm}, 7.939 \mathrm{~mm}, 9.881 \mathrm{~mm}$, and $14.97 \mathrm{~mm}$, respectively. Research results can serve as design bases for the pile foundation of multistorey buildings located in landslide areas of Baishi Mountain in the southwest of China and also as references for the engineering application of pile foundation in similar geological fracture areas.

\section{Introduction}

Due to its high bearing capacity, small settlement, good stability, and other characteristics, pile foundation has been extensively studied by many scholars around the world in the past few decades. In the early research of pile foundation, the integrity of pile body and the bearing capacity of single pile are mainly tested by low strain integrity testing $[1,2]$, acoustic transmission method [3], penetration test (CPT) [4], and other methods, but the bearing capacity of pile foundation obtained by the above methods is only estimated value.

The field static load test method is the most reliable method to determine the bearing capacity. In recent years, according to the field static load test research of bored piles with different length-diameter ratios, it has been confirmed that the bearing performance of the piles is related to the length-diameter ratio of the piles and the construction technology of the pile foundation itself; increasing the bottom of pile and no sediment at the bottom will improve the bearing capacity of pile, and the larger the length-diameter ratio, the lower the bearing capacity [5-7]. In addition to the specific length-diameter ratio, the rock-soil properties [8] where the pile foundation is located also affect the bearing capacity. Therefore, in the foundation design, the effective stress distribution of the soil around and below the foundation unit must be determined first, because it is the basis for 
design analysis [9]. Until now, scholars around the world have also carried out extensive load test research on the bearing capacity of pile foundation in different rock and soil mass, including laboratory tests $[10,11]$ and field static load tests of pile foundation in different geologic structure in different regions. Guo and Ghee [12] studied the influence of lateral movement of upper soil mass on pile bending moment and soil reaction force through model test and found that when there is vertical load on the pile top, the maximum deformation of the pile body, the maximum bending moment, and the soil reaction caused by the movement of the upper soil mass are obviously smaller than those caused by no vertical load on the pile top. According to Zhou et al. [13], taking Wuding Expressway project in loess region as an example, the shaft skin resistance of six test piles is studied through static load testing and multiparameter statistical analysis. The multiparameter statistical analysis method is compared with the static load test results, and the error is controlled within 20\%. Hai and Fellenius [14] conducted static loading tests using single-level O-cells at Ho Chi Minh City, Vietnam, and showed the shaft resistance to be postpeak softening, and the pile toe stress-movement responses were essentially linear and almost identical for the two piles. With the development of the computer numerical simulation technology such as finite element method and finite difference method, the numerical simulation method is gradually applied to the prediction and evaluation of the bearing capacity of pile foundation $[15,16]$.

The numerical simulation calculation results and the experimental results are easily affected by soil properties, and there are few researches on the bearing capacity of pile foundation in the landslide area. Therefore, in this paper, we study the field in which the vertical static load test of large diameter manually bored cast-in-place pile was carried out in the Baishi Mountain located in southwest of China, to study the bearing performance and load transfer law of pile foundation in the slope area.

\section{Soil Conditions}

The test is carried out in the slope area of Baishi Mountain. The rocks in the test site are in different sizes and shapes, and the geologic structure is uneven. Before the static load test of pile foundation, multichannel transient surface wave test and superheavy $\left(\mathrm{N}_{120}\right)$ cone dynamic sounding test are conducted on the test site area in order to determine the physical and mechanical properties of gravel soil.

In the multichannel transient surface wave test, DZQ242A series high-resolution seismograph and 24-pound hammering source are used. There are 10 observation systems with a distance of $2 \mathrm{~m}$ between each two. The minimum offset distance is 10 meters, the sampling interval is $512 \mu \mathrm{s}$, and the total number of sampling points is 1024. In view of the difference in frequency and propagation speed between surface wave and other seismic wave fields and the dispersion characteristic of surface wave, $f-k$ analysis method [17] was used in data processing, and the shear wave velocity profile was generated after Kriging meshing and Gaussian smoothing. As shown in Figure 1, the abscissa is the section length $L(\mathrm{~m})$ and the ordinate is the formation depth $Z(\mathrm{~m})$. (m)

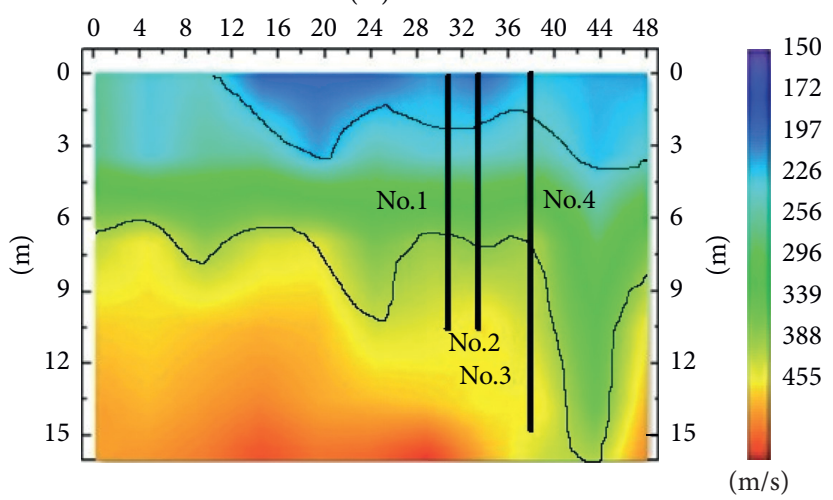

Figure 1: Profile of shear wave velocity on site area.

According to the profile of shear wave velocity in Figure 1, the site can be divided into four layers. The first layer is cultivated soil with a depth of about 1 meter, and an average shear wave velocity is less than $150 \mathrm{~m} / \mathrm{s}$. The second layer is sandy soil, a depth about 1 to 3 meters, and an average shear wave velocity of 150 to $200 \mathrm{~m} / \mathrm{s}$. The third layer is silty clay with a relatively a small amount of gravel soil content, a depth about 3 to 6 meters, and an average shear wave velocity of 200 to $250 \mathrm{~m} / \mathrm{s}$. The fourth layer is gravel soil with a depth of more than $6 \mathrm{~m}$ and a wave velocity greater than $250 \mathrm{~m} / \mathrm{s}$. In the longitudinal direction, the wave velocities of surface soil and deep soil are quite different. In the transverse direction, the distribution of chromatic aberration in shear wave velocity image is chaotic. According to the above findings, it can be concluded that the shear wave velocity of rock and soil mass on the site changes greatly and the testing site is composed of many kinds of rock and soil with different sizes and shapes and shows the characteristics of strong nonuniformity.

Cone dynamic sounding test is a commonly used in-situ test method to evaluate the mechanical properties of granular soil. In this test, 4 locations are selected as test points and superheavy $120 \mathrm{~kg}$ dynamic penetrometer was used. The statistical results of penetration hammering counts are shown in Table 1. The relationship between hammering counts and penetration depth is shown in Figure 2.

According to the standard values of the superheavy $\mathrm{N}_{120}$ dynamic sounding hammering count of the four test points and China Code for Investigation of Geotechnical Engineering (GB50021 2016) [18], it can be concluded that the density of gravel soil in the site is of medium density. From the single-hole hammering count obtained from the test, it can be seen that high hammering counts and low hammering counts are interwoven, indicating that the particle size of rock and soil mass on the site is complicated and the uniformity is poor. In order to investigate the grain size relationship of soil and rock of each test pile, the field stratified sampling and screening test was carried out on the gravel soil. Due to the crushing of machines and tools, the topsoil (about $1 \mathrm{~m}$ thick) was removed before the test. Samples were taken from the point of $1 \mathrm{~m}$ and then sampled at intervals of $3 \mathrm{~m}$ in sections, with each section sampling about $200 \mathrm{~kg}$. After sampling, the soil was dried in an oven $\left(105 \sim 110^{\circ} \mathrm{C}\right)$, and the block stones with a short side diameter of more than $60 \mathrm{~mm}$ were weighed. Then, the remaining 
TABLE 1: Statistical table of test indexes of superheavy dynamic sounding test $\left(\mathrm{N}_{120}\right)$.

\begin{tabular}{lccccc}
\hline Test point & Scope of statistics $(\mathrm{m})$ & Range value & $\begin{array}{c}\text { Average hammering counts for } \\
\text { single-hole correction } N_{120}\end{array}$ & Standard value & Variable coefficient \\
\hline No. 1 & $0.3 \sim 10.0$ & $0.96 \sim 19.552$ & 7.55 & 4.60 & 0.609 \\
No. 2 & $0.3 \sim 10.0$ & $1.82 \sim 19.552$ & 8.82 & 4.36 & 0.49 \\
No. 3 & $0.3 \sim 10.0$ & $1.88 \sim 17.766$ & 8.56 & 3.86 & 0.450 \\
No. 4 & $0.3 \sim 15.0$ & $1 \sim 20.032$ & 7.88 & 3.98 & 0.505 \\
\hline
\end{tabular}

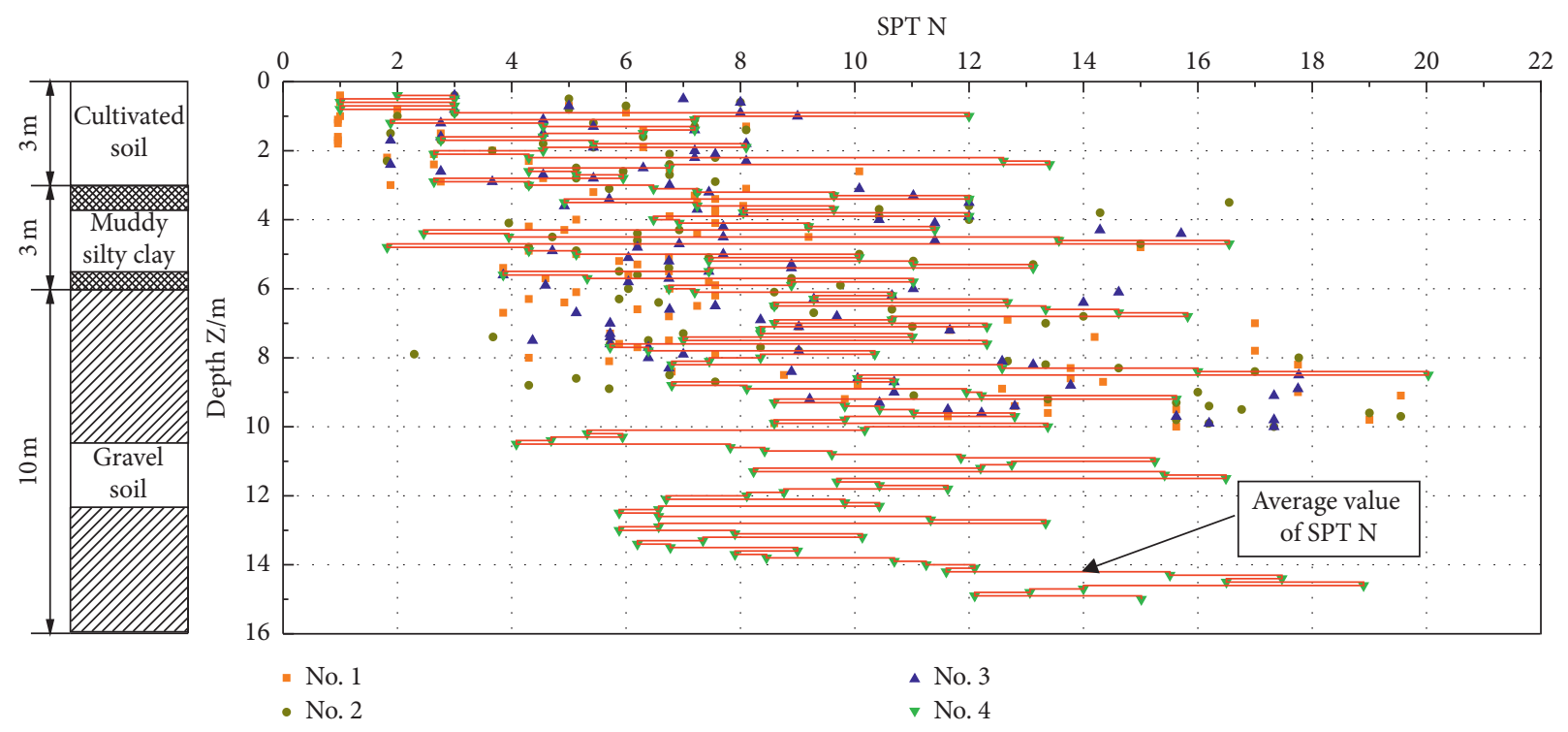

Figure 2: SPT $\mathrm{N}_{120}$ values with depth.

soil was placed on the standard screen selected in batches of $10 \mathrm{~kg}$ each time for vibration screening for 10 to 15 minutes. Finally, the mass of samples on each screen was weighed and the soil gradation was calculated. The statistical analysis of test data is shown in Table 2. And the grain size distribution curves at the site of $A, B, C$, and $D$ are shown in Figure 3.

During on-site screening, at positions $A, B$, and $C$, with a depth from 1 to $4 \mathrm{~m}$, the particle sizes of rock and soil bodies differ greatly, with missing intermediate particles, faults, nonuniform soil particles, and easy compaction. At $D$ screening positions, the particles with a depth of less than $4 \mathrm{~m}$ are relatively uniform and easy to compact. According to statistical data, the nonuniformity coefficient $\mathrm{Cu}$ of gravel soil is 4.042 to 35.641 ; the average value is 9.461 . The curvature coefficient $C c$ is 2.45 to 4.359 , with an average value of 3.227. According to the grain size distribution curves (as seen in Figure 3), it can be seen that, on the site, there is a large difference in particle size, soil particles are nonuniform, and particles are loose. The site is a poorly graded site and is not conducive for stabilizing the foundation.

According to the results of the above-mentioned multichannel transient surface wave test, superheavy $\left(\mathrm{N}_{120}\right)$ cone dynamic sounding test, and gravel soil particle grading test, it is concluded that the geological structure of the site is complex, the content of gravel soil is high, and the nonuniformity between particles is high. Based on the preliminary engineering survey report and the above-mentioned in-situ test results, detailed physical parameters of the rock and earth mass on the site are obtained, as shown in Table 3.
TABle 2: Statistics and analysis of gravel soil screening test and conventional physical parameters.

\begin{tabular}{lccc}
\hline Specimen number & Sample depth $(\mathrm{m})$ & $C u$ & $C c$ \\
\hline$A$ & $1 \sim 4$ & 15.643 & 4.357 \\
$A$ & $4 \sim 7$ & 4.042 & 2.494 \\
$A$ & $7 \sim 10$ & 6.228 & 3.232 \\
$B$ & $1 \sim 4$ & 17.627 & 3.303 \\
$B$ & $4 \sim 7$ & 5.297 & 3.175 \\
$B$ & $7 \sim 10$ & 4.66 & 2.763 \\
$C$ & $1 \sim 4$ & 35.641 & 4.359 \\
$C$ & $4 \sim 7$ & 7.738 & 3.806 \\
$C$ & $7 \sim 10$ & 5.333 & 2.91 \\
$D$ & $1 \sim 4$ & 9.133 & 2.737 \\
$D$ & $4 \sim 7$ & 4.67 & 2.747 \\
$D$ & $7 \sim 10$ & 6.853 & 4.123 \\
$D$ & $10 \sim 13$ & 5.48 & 2.72 \\
$D$ & $13 \sim 15$ & 4.105 & 2.45 \\
Statistics & & 14 & 14 \\
Average value & & 9.461 & 3.227 \\
Maximum value & & 35.641 & 4.359 \\
Minimum value & & 4.042 & 2.45 \\
\hline
\end{tabular}

\section{Pile Test Program}

3.1. Pile Foundation Construction. According to the abovementioned in-situ test results, in order to study the internal force characteristics of pile shaft axial force, shaft skin resistance, ultimate tip resistance, and other internal force 


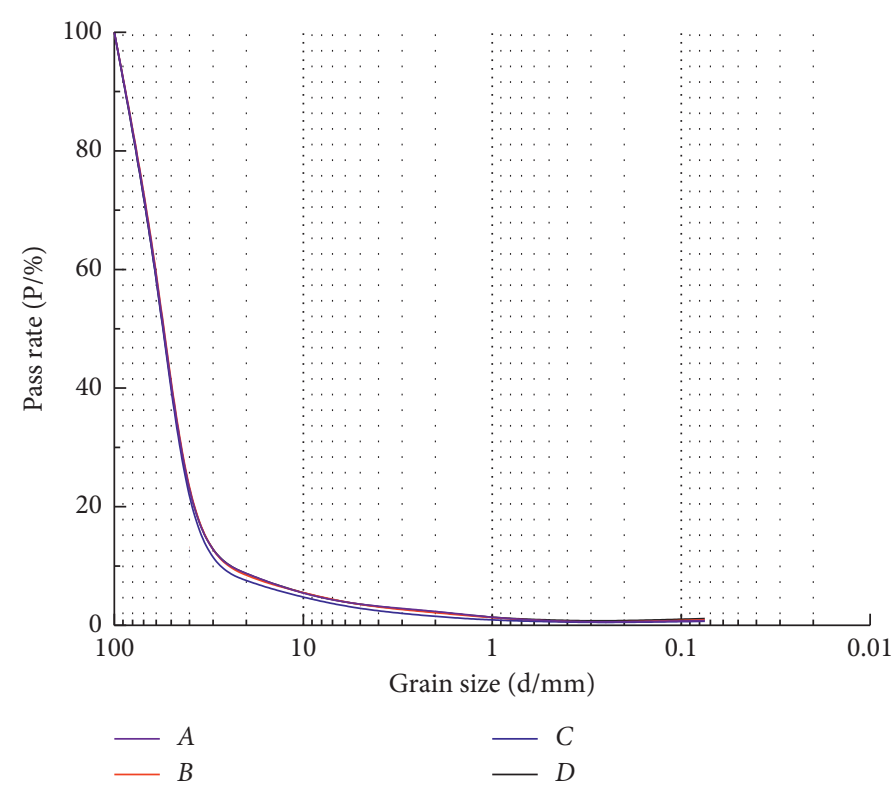

Figure 3: The grain size distribution curves at the site of $A, B, C$, and $D$.

Table 3: Physical and mechanical properties of soil.

\begin{tabular}{lccc}
\hline Soil layer & Weight density $\gamma\left(\mathrm{kN} / \mathrm{m}^{3}\right)$ & Internal friction angle $\varphi\left(^{\circ}\right)$ & Cohesion $C(\mathrm{kPa})$ \\
\hline Cultivated soil & 18 & 18 & 15 \\
Sandy soil & 19 & 21 & - \\
Silty clay & 19 & 13 & 23 \\
Gravel soil & 20 & 25 & 5 \\
\hline
\end{tabular}

characteristics of pile foundation in gravel soil bearing stratum of different depths, static load tests are carried out in the area where shear wave velocity is relatively uniform, i.e., within 30 to $38 \mathrm{~m}$ along the length direction of wave velocity profile. The test pile is a C35 manually excavated cast-in-place pile with a diameter of $0.9 \mathrm{~m}$. A total of 4 piles were arranged. See Figures 1 and 4 for the plan layout and pile numbers. The characteristic parameters of each tested pile are shown in Table 4.

The No. 1 pile is empty-bottom pile (as shown in Figure 5(a)) and Nos. 2, 3, and 4 piles are solid-bottom piles (as shown in Figures 5(b) and 5(c), resp.). The empty-bottom pile is welded to a $20 \mathrm{~mm}$ thick circular steel plate at the bottom of the steel cage; the diameter of the steel plate is $(850 \mathrm{~mm})$ slightly smaller than the diameter of the pile hole. When pouring concrete, the steel cage is suspended to make the bottom of the steel cage suspended $1 \mathrm{~m}$.

There are $12 \Phi 14$ HRB 400 reinforcements used as main reinforcements of all test piles. The inner stirrup adopts HPB235 reinforcement with a diameter of $16 \mathrm{~mm}$, and it starts from $2 \mathrm{~m}$ below the top of the longitudinal reinforcement and is evenly arranged each $2 \mathrm{~m}$. The outer stirrup adopts HPB235 reinforcement with a diameter of $8 \mathrm{~mm}$, and it is arranged from below the longitudinal rib top. The spacing between the outer stirrup and the longitudinal rib top is $100 \mathrm{~mm}$ within the range of $3 \mathrm{~m}$, and the rest of the space is $200 \mathrm{~mm}$. At the same time, 6 anchor piles with a length of $15 \mathrm{~m}$ are arranged, in 4 of them the diameter is $1300 \mathrm{~mm}$, and the others' diameter is $1100 \mathrm{~mm}$. The

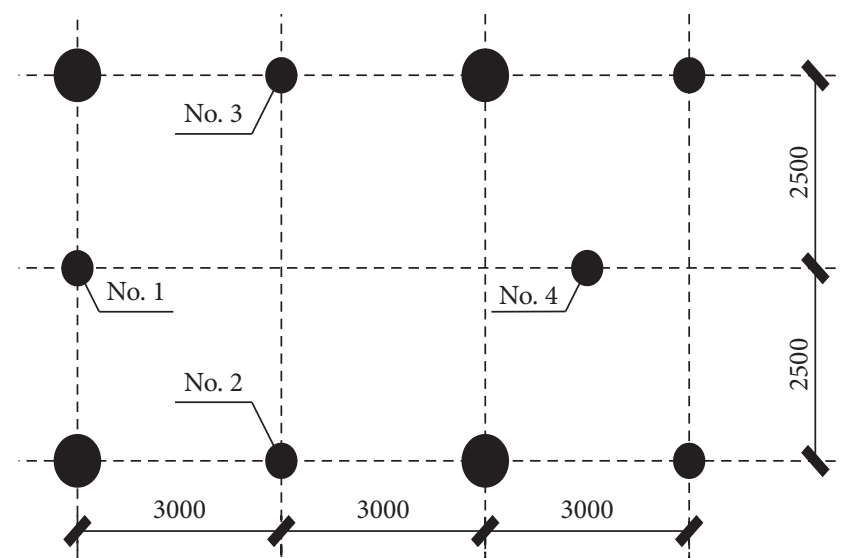

Figure 4: Layout of pile position.

longitudinal bar of anchor piles is composed of 16 and 20 finished reinforcing bars with the diameter of $28 \mathrm{~mm}$. The concrete reinforcement layout and strain gauges layout of the test pile are seen in Figure 5.

3.2. Measuring Instrument. Resistive strain gauges are symmetrically arranged on the main reinforcement (as shown in Figure 5) to measure the vertical strain of reinforcement and pile body. The DM-YB1840 dynamic and static strain testing system automatically collects strain data and calculates axial force on pile body and shaft skin 
TABLE 4: The characteristic parameters of each tested pile.

\begin{tabular}{lcccr}
\hline Piles' no. & Piles' length $L(\mathrm{~m})$ & Piles' diameter $D(\mathrm{~mm})$ & Concrete strength & Form \\
\hline No. 1 & 10 & 900 & C35 & Empty-bottom \\
No. 2 & 10 & 900 & C35 & Solid-bottom \\
No. 3 & 10 & 900 & C35 & Solid-bottom \\
No. 4 & 15 & 900 & C35 & Solid-bottom \\
\hline
\end{tabular}
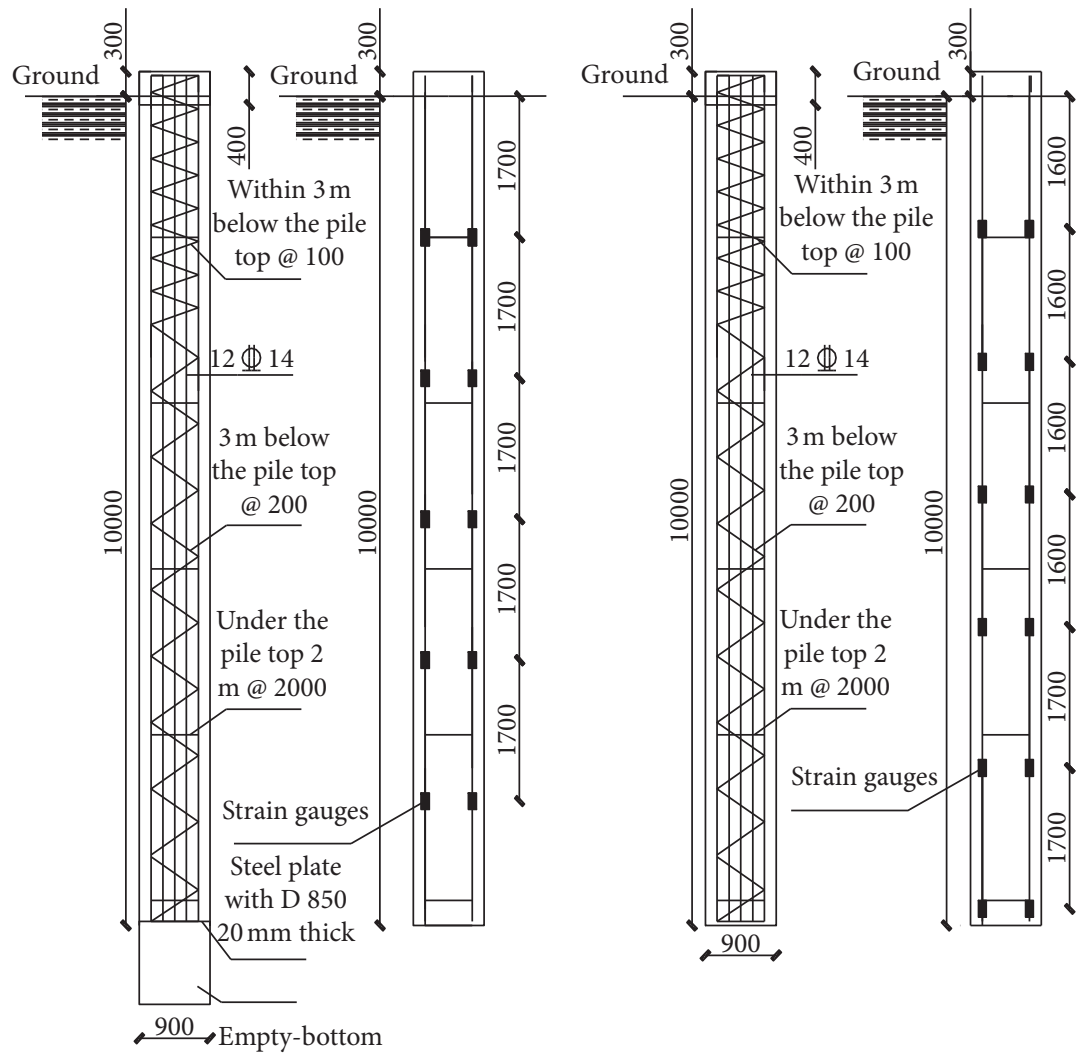

(a) (b)

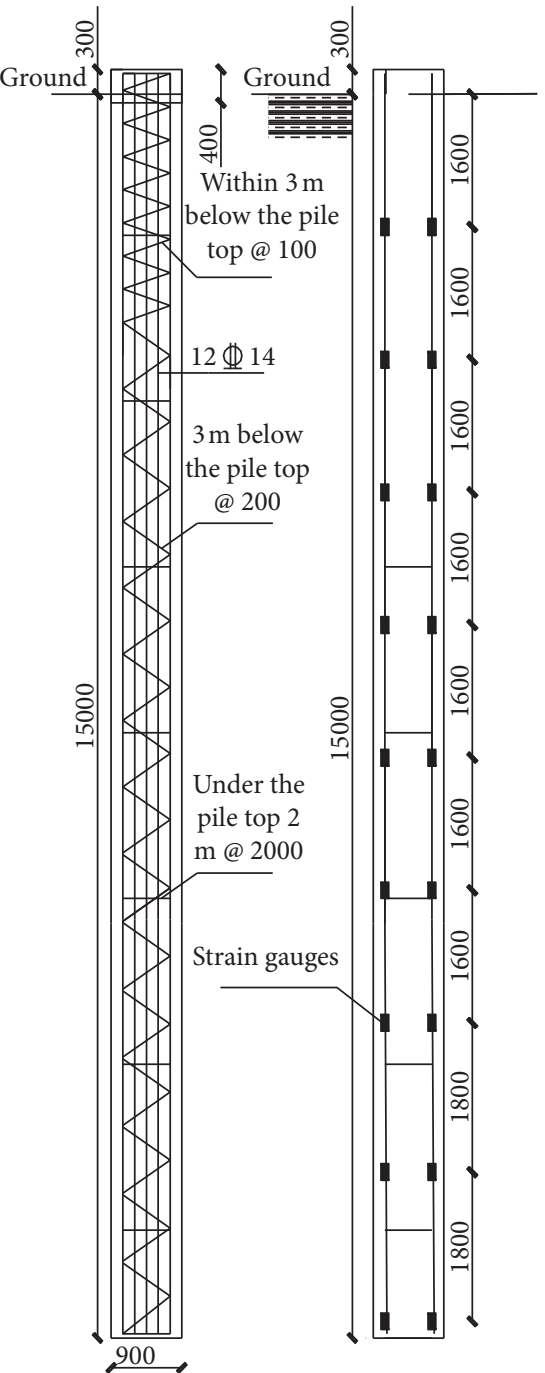

(c)

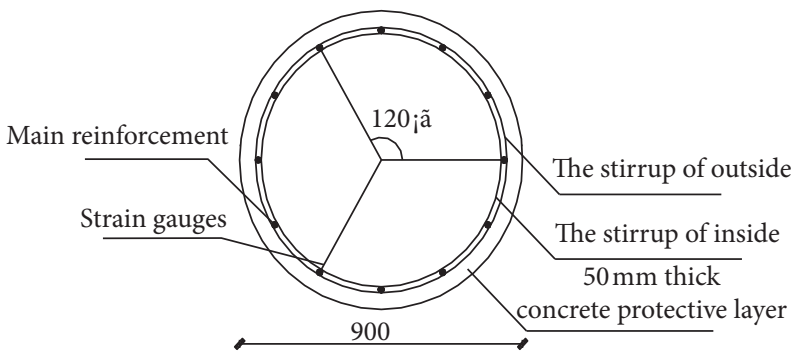

(d)

FiguRE 5: The reinforcement layout and strain gauges layout of the test pile. (a) Empty-bottom pile No. 1. (b) Solid-bottom pile No. 2 and No. 3. (c) Solid-bottom pile No. 4. (d) Plan of layout of pile. 
resistance. The embedment of strain gauges shall be carried out strictly in accordance with the operating instructions and maintenance work shall be done to improve the success rate; for the on-site embedding photo of strain gauges, see Figure 6.

3.3. Static Load Method of Pile Foundation. In the YD10000200 hydraulic jack applying load, the load reaction force is provided by anchor pile. Four FP-50 displacement sensors were used for settlement, which were installed on the reference beam at the top of the test pile. The support of the sensor was fixed on the jack with magnetic bearing, and the reference beam was fixed on the steel beam in an independent position unaffected by deformation calibrating the displacement sensor with the displacement sensor calibration table before the test and using a force transducer to calibrate the accuracy of the load on the jack. The Y-LINK static load test system automatically collects and stores test data. The vertical compressive static load device of single pile is shown in Figure 7(a), and the photo of field static load test is shown in Figure 7(b).

The test is carried out according to China Technical Code for Testing of Building Foundation Piles (JGJ106-2014) [19]; the specific steps are as follows.

(1) In the test, the step loading method was adopted; (2) measuring the settlement every 5 minutes, 10 minutes, and 15 minutes after each step of loading was applied, every 15 minutes after that, and every 30 minutes after a total of 1 hour and then loading stopped. (3) The settlement per hour could not exceed $0.1 \mathrm{~mm}$. When it occurred twice in succession, it was considered to be relatively stable and the next step of loading could be applied. (4) When the settlement of the pile was 5 times of the settlement under the previous load and the total settlement at the top of the pile exceeded $40 \mathrm{~mm}$, or the settlement of the pile was greater than 2 times of the settlement under the previous load, and had not reached a stable state after 24 hours, loading stopped.

3.4. Test Results of Pile Foundation. The line type of loaddisplacement (Q-S) curve in static load test can macroscopically reflect pile body's failure mechanism and failure mode of soil around pile [20]. When the load is small, the displacement curve tends to develop linearly and is in the elastic stage. With the increasing load, the pile gradually changes from elastic deformation to elastic-plastic deformation. As the load continues to increase, the displacement increases sharply and enters the plastic stage and the pile reaches the failure state. The Q-S curves of piles Nos. 1, 2, 3, and 4 are shown in Figure 8 .

It can be seen from Figure 8 that the Q-S curve of No. 1 pile has obvious inflection point, indicating that it is a steep drop curve. The pile top load corresponding to the inflection point of Q-S curve is taken as the ultimate bearing capacity of the test pile [21]. The Q-S curves of the other three piles have similar trends, and there is no obvious steep drop section, indicating that they are slowly changing curves, so the ultimate bearing capacity is confirmed according to 4.4.2 in The Technical Specification of China Building Foundation
Piles. The bearing capacity under ultimate load of No. 1 pile is $3600 \mathrm{kN}$, and the corresponding pile top settlement is $12.89 \mathrm{~mm}$; the maximum load is $4000 \mathrm{kN}$ and the maximum settlement is $40.68 \mathrm{~mm}$; similarly, the maximum loading load of Nos. 2, 3, and 4 piles and their corresponding pile top displacement values, bearing capacity under ultimate load and corresponding pile top displacement, and settlement values are shown in Table 5.

Figure 9 shows the S-lgt curve of settlement of each pile with time, which can further explain the value of ultimate bearing capacity. At the last step of loading, an obvious downward bending is shown in the displacement of the four piles, the displacement exceeded $40 \mathrm{~mm}$, and the pile reaches the failure state [22].

\section{Discussion}

4.1. The Characteristics of Pile Shaft Force Transfer. The reinforcement strain $\varepsilon_{i}(\mu \varepsilon)$ at the corresponding depth is directly measured by the strain gauges meter embedded, and then the reinforcement stress $\sigma_{i}$ is calculated according to

$$
\sigma_{s i}=K \cdot\left(\varepsilon_{0}-\varepsilon_{i}\right) \text {, }
$$

where $\sigma_{i}$ is the stress on the reinforcement; $K$ is calibration coefficient indicated by the manufacturer and its value ranges from 0.6 to $0.8 ; \varepsilon_{i}$ is average strain measured by strain gauges on the same section; $i$ is the serial numbers of the buried sections of the strain gauges, $i=1,2, L, n$ are arranged from top to bottom.

According to Hooke's law and the stress on the reinforcement, the real strain value of the strain gauges string is calculated:

$$
\varepsilon_{s i}=\frac{\sigma_{s i}}{E_{s}}
$$

where $\varepsilon_{s i}$ is the real strain of the strain gauges string; $E_{s}$ is the elastic modulus of reinforcement, with a value of $2.04 \times 10^{4} \mathrm{MPa} ; \sigma_{i}$ and $i$ are the same as in formula (1).

Assuming that the compression amount of concrete is equal to the real strain value of the strain gauges string and the cross-sectional area of the pile is unchanged, the concrete stress can be obtained according to

$$
\sigma_{c i}=\varepsilon_{s i} \cdot E_{c}
$$

where $\sigma_{c i}$ is the concrete stress value; $\varepsilon_{s i}$ is the real strain of strain gauges string; $E_{c}$ is the modulus of elasticity of concrete, with a value of $10^{4} \mathrm{MPa} ; i$ is the same as in formula (1).

Finally, the respective internal forces are obtained by multiplying stress values by the respective cross-sectional areas, and then the pile axial force of this section is obtained by the stress of reinforcements plus the stress of concrete, and the axial force of other cross-sectional pile bodies can be obtained similarly; the calculation formula is as follows:

$$
Q_{i}=\sigma_{c i} A_{c i}+\sigma_{s i} A_{s i},
$$

where $Q_{i}$ is the axial force of tested section; $\sigma_{c i}$ and $\sigma_{s i}$ are the same as in formulas (3) and (1), respectively. $A_{c i}$ is the 


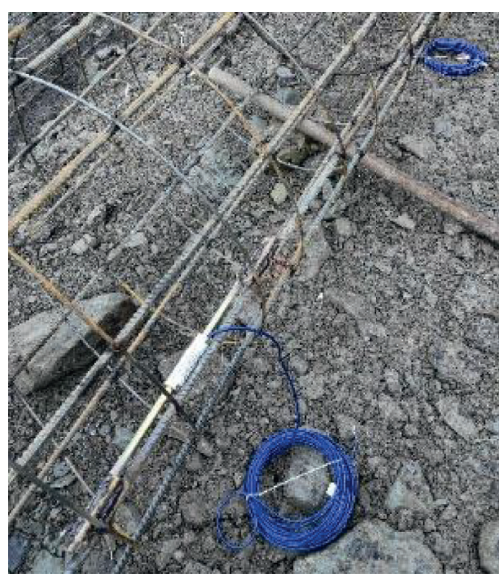

(a)

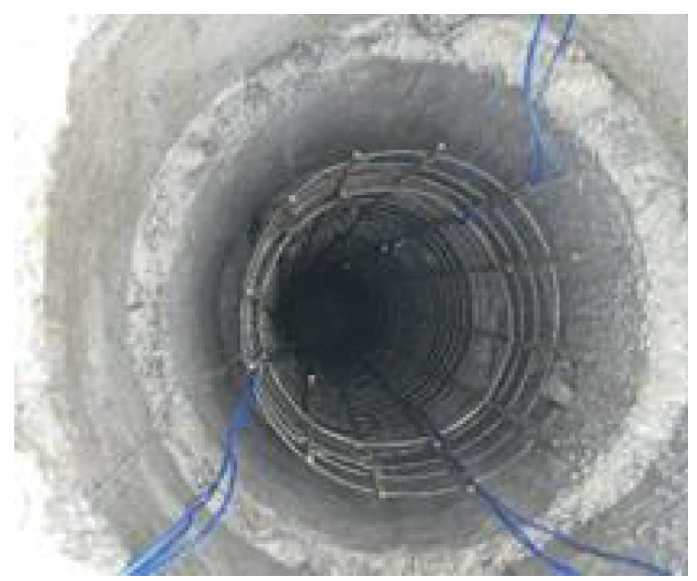

(b)

Figure 6: Site photo of strain gauges embedding. (a) Part photo. (b) The overall photo.

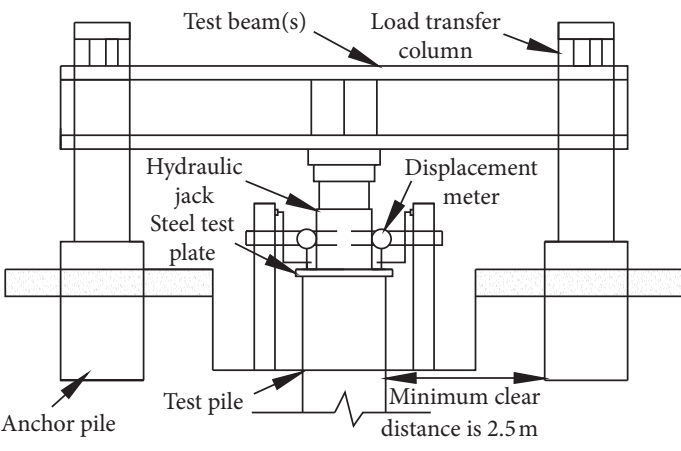

(a)

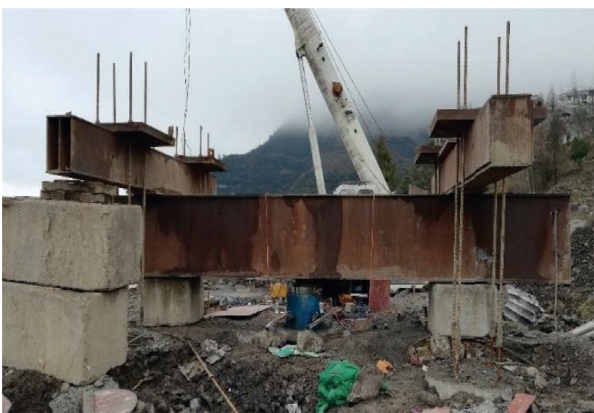

(b)

Figure 7: Schematic diagram and field photo of static load test. (a) Schematic diagram. (b) Photograph.

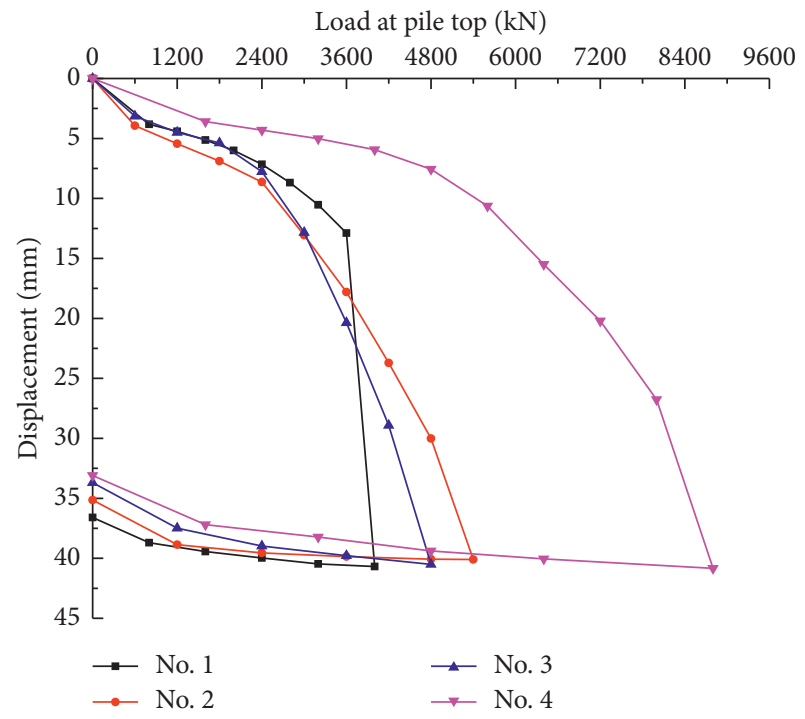

FIGURE 8: Load-displacement curve of static load test.

concrete area of pile body, $0.63585 \mathrm{~m}^{2} ; A_{s i}$ is the area of reinforcement in pile body, $1.84632 \times 10^{-3} \mathrm{~m}^{2}$.

Figures 9(a)-9(d) show the axial force distribution of piles Nos. 1, 2, 3, and 4 with depth under different loading steps, respectively. With the increase of loading steps, axial force is gradually generated at the lower part of each solid-bottom pile, and pile tip resistance is gradually mobilized [23]. When reaching the ultimate load, pile tip resistance of piles Nos. 2, 3, and 4 is $2100 \mathrm{kN}, 1418 \mathrm{kN}$, and $3463 \mathrm{kN}$, respectively. The first pile is an empty-bottom pile; with the increase of load, axial force is gradually generated at the lower part of the pile body. After reaching the ultimate bearing capacity, the load will continue to be applied, and the displacement of pile top will rapidly increase from the original $12.89 \mathrm{~mm}$ to $40.68 \mathrm{~mm}$. This is because the first pile is an empty-bottom pile, and there is no soil at the bottom to generate tip resistance. When the shaft skin resistance reaches the maximum value and cannot resist the axial force in the vertical direction, if the load continues to be applied after reaching the ultimate bearing capacity, sudden settlement of the pile body occurs and the settlement exceeds the limit specified in the specification, indicating that pile failure has occurred.

It can be seen from the stress conditions of the solidbottom pile, the empty-bottom pile, the 10-meter-long pile body, and the 15-meter-long pile body in Figure 10 that the axial force of the empty-bottom pile and the solid-bottom pile is relatively small at the initial loading step. With the increase of loading step, the axial force gradually develops 
TABLE 5: Results of static load test.

Pile number Maximum load $(\mathrm{kN})$ Maximum load settlement $(\mathrm{mm})$ Bearing capacity under Settlement under

\begin{tabular}{|c|c|c|c|c|c|}
\hline No. 1 & 4000 & 40.68 & 3600 & 12.89 & 10.06 \\
\hline No. 2 & 5400 & 40.1 & 4800 & 30.01 & 12.36 \\
\hline No. 3 & 4800 & 40.51 & 4200 & 28.92 & 16.84 \\
\hline No. 4 & 8800 & 40.83 & 8000 & 26.76 & 18.94 \\
\hline
\end{tabular}

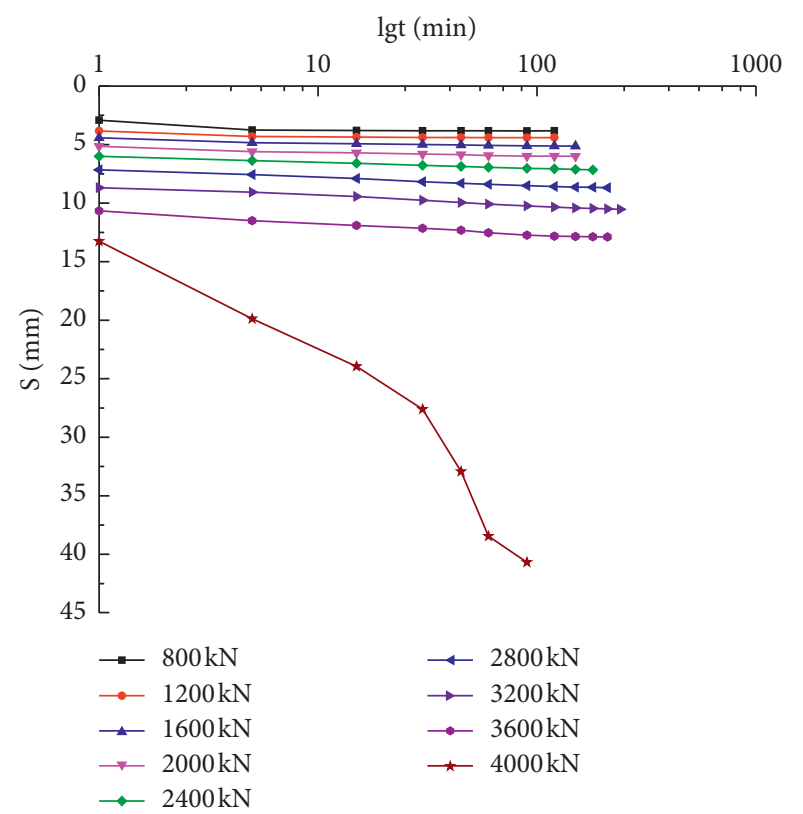

(a)

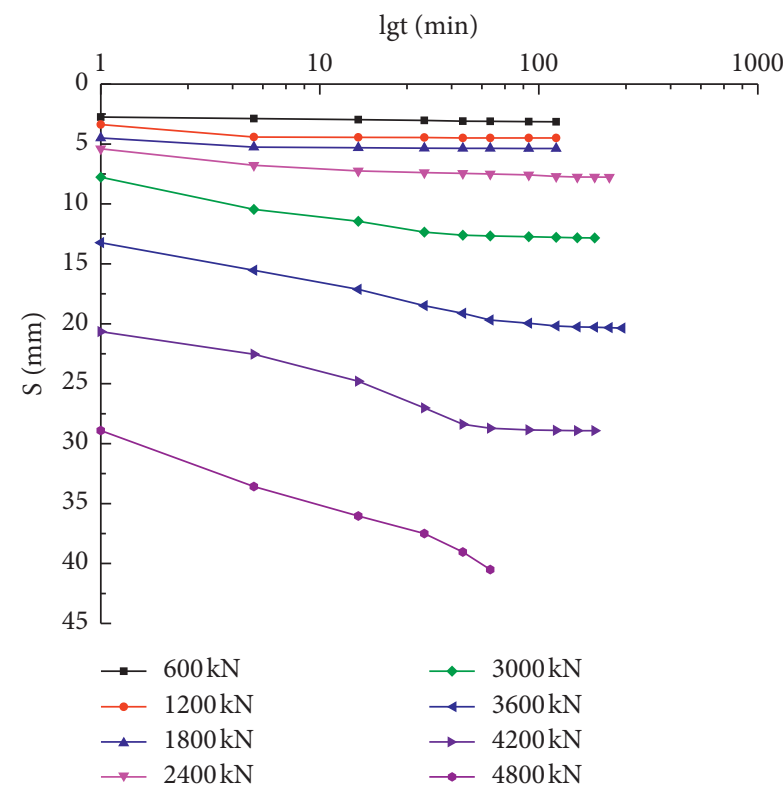

(c)

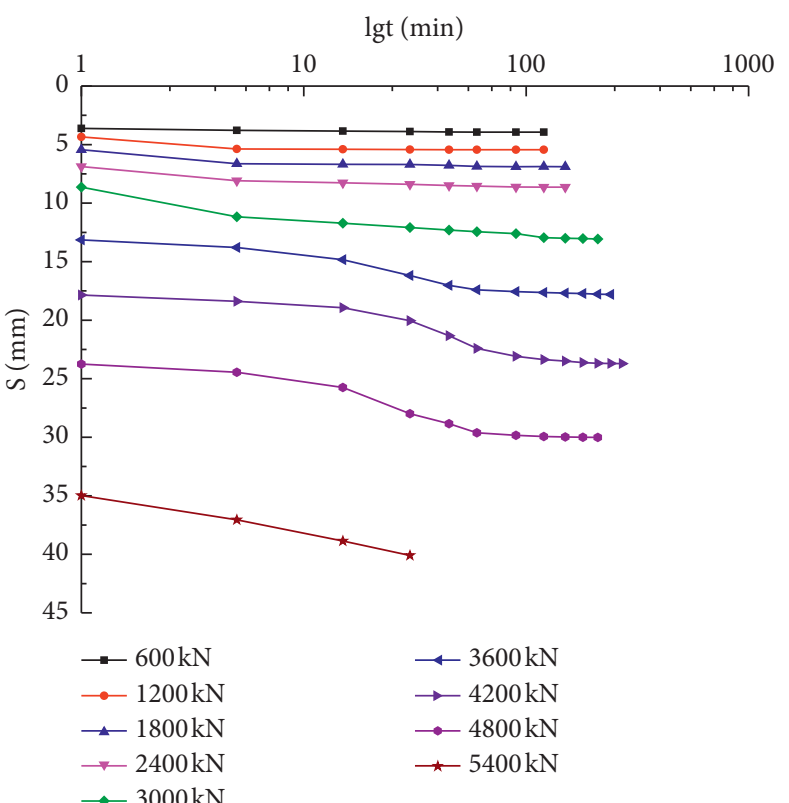

(b)

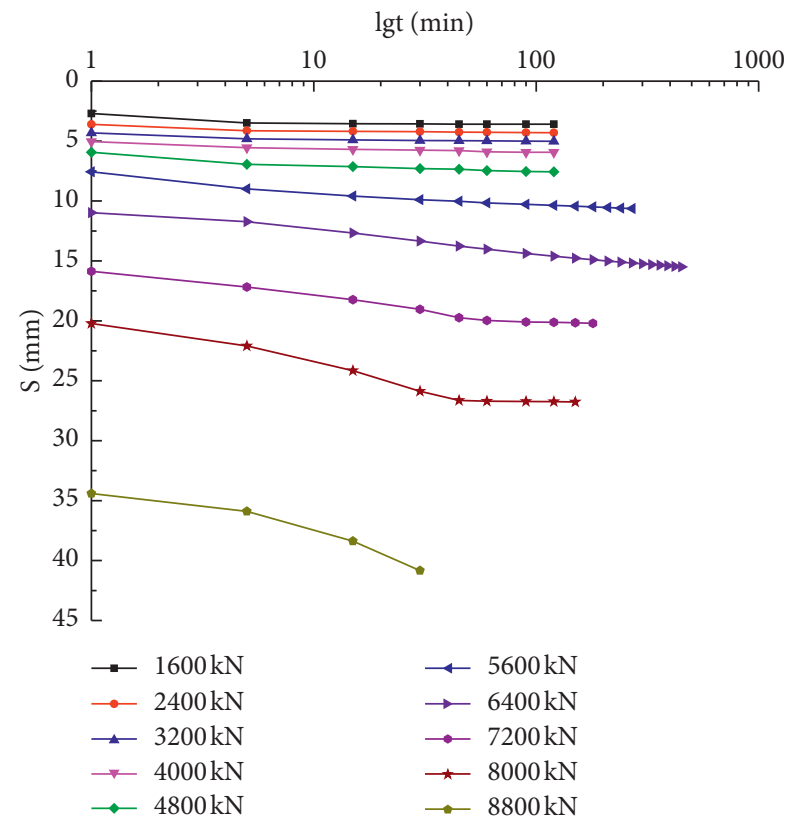

(d)

FIgure 9: S-lgt curve of each pile. (a) No. 1 pile. (b) No. 2 pile. (c) No. 3 pile. (d) No. 4 pile. 
Axial force $(\mathrm{kN})$

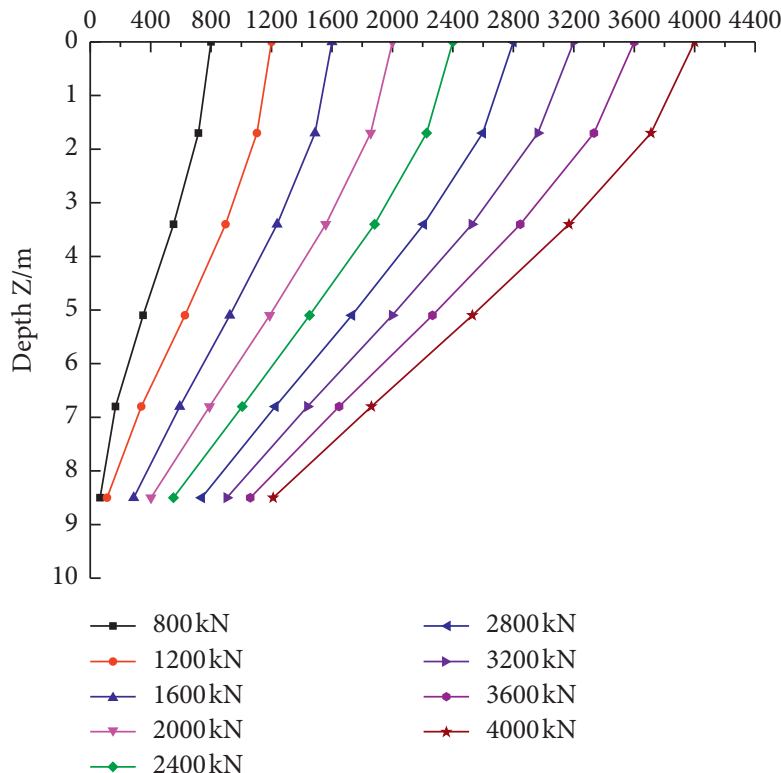

(a)

Axial force $(\mathrm{kN})$

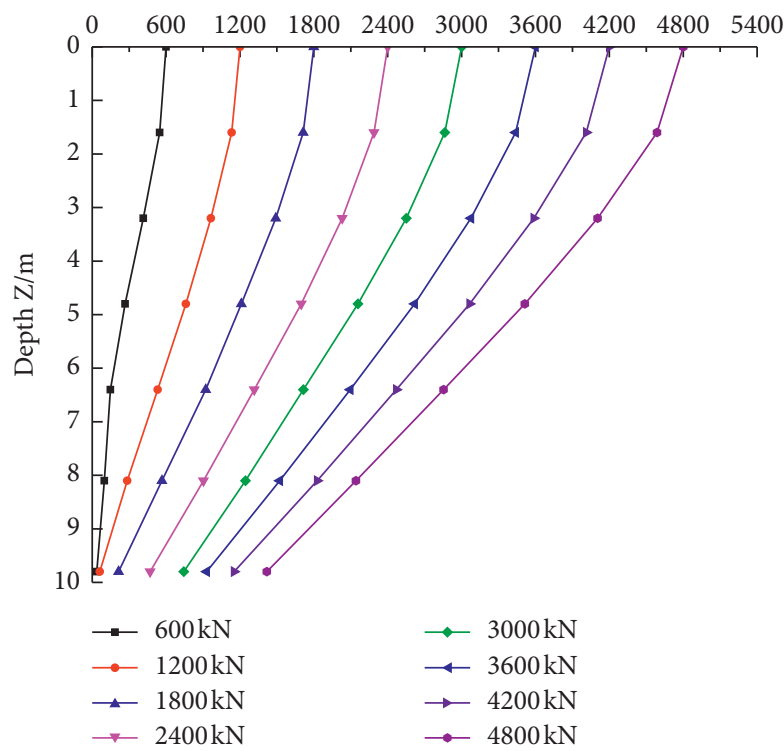

(c)

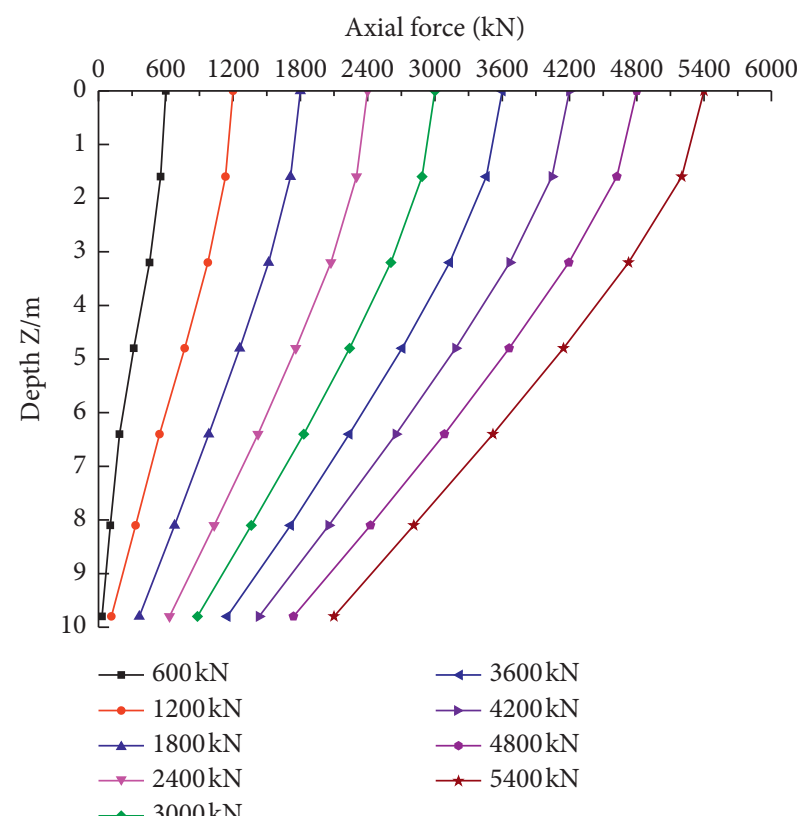

(b)

Axial force $(\mathrm{kN})$

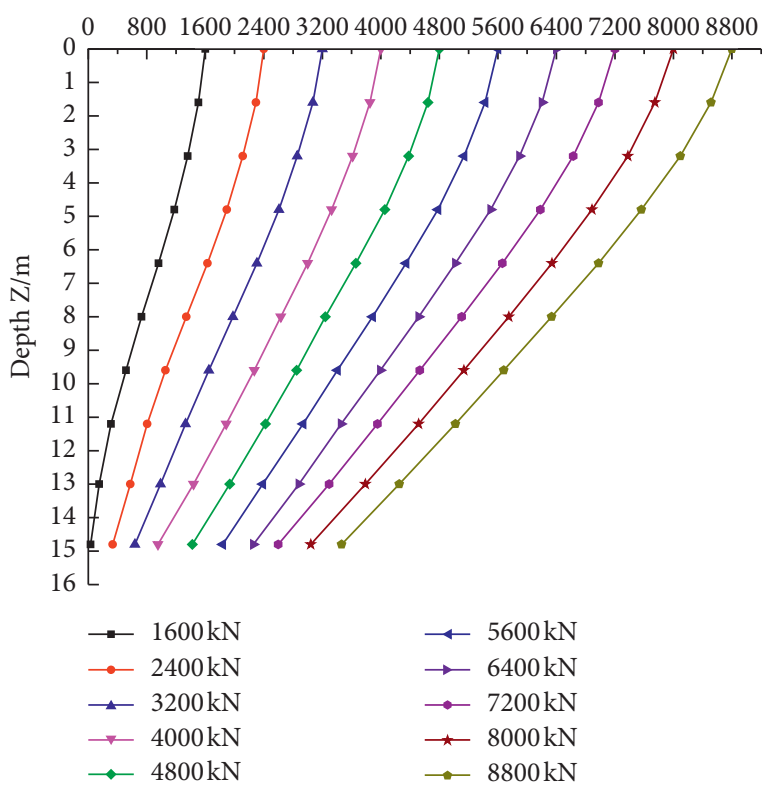

(d)

Figure 10: Distribution curve of axial force of each pile. (a) No. 1 pile. (b) No. 2 pile. (c) No. 3 pile. (d) No. 4 pile.

and transmits to the pile bottom and decreases with the increase of the depth. Under different loading steps, the attenuation rate of axial force curve is different. The attenuation rate of axial force curve reflects the development of shaft skin resistance. In low loading steps, the attenuation rate of axial force curve is not fast and relatively uniform. With the increase of loading steps, the attenuation rate of axial force curve at the upper part of pile body is not fast, while the attenuation rate of axial force curve at the lower part of pile body is obvious, which shows that no matter it is an empty-bottom pile or solid-bottom pile, the force transmission characteristics are similar. With the increase of loading steps, the axial force gradually transmits to the lower part of the pile body. If load continues to be applied after reaching the ultimate load, the empty-bottom pile will be suddenly destroyed while the solid-bottom pile will be able to bear due to soil in the lower part and will show a slow change.

4.2. Analysis of Characteristics of Shaft Skin Resistance of Pile Body. Based on the principle of static balance, regardless of the influence of pile body weight [24], the pile shaft skin 


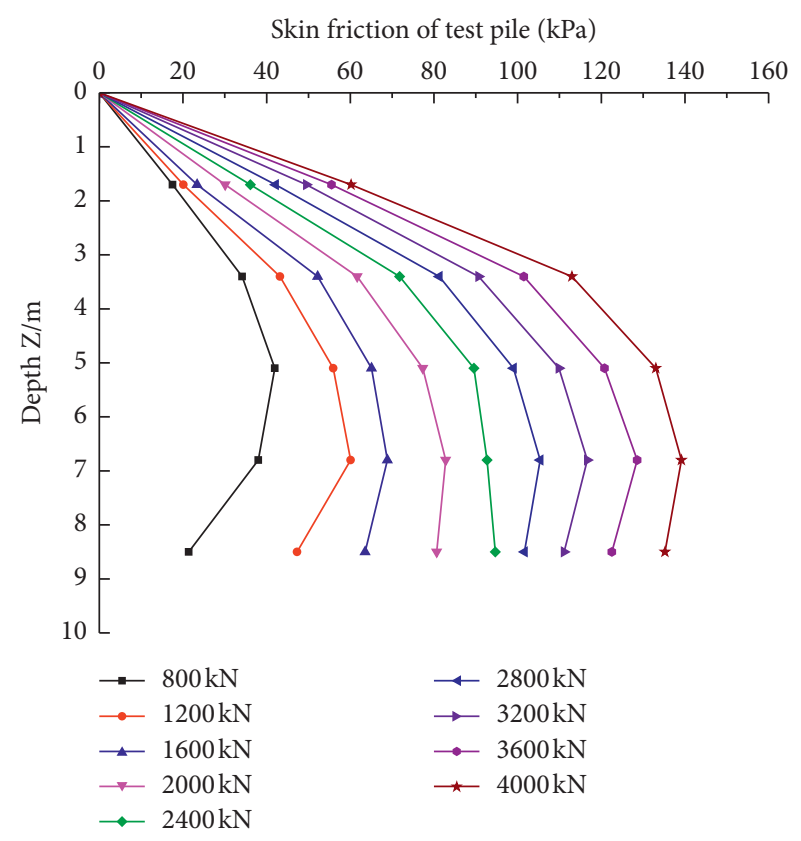

(a)

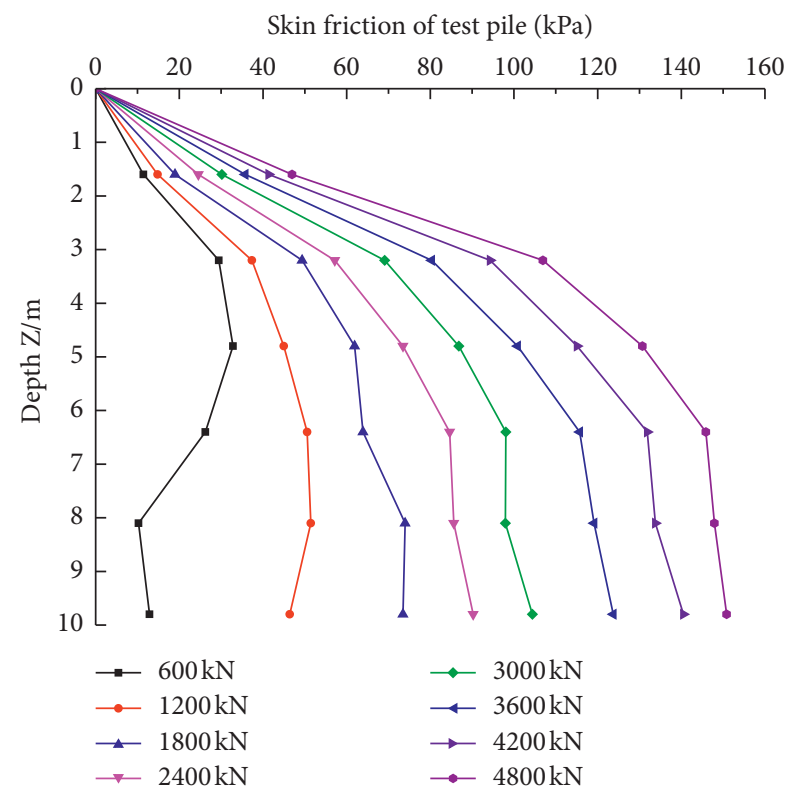

(c)

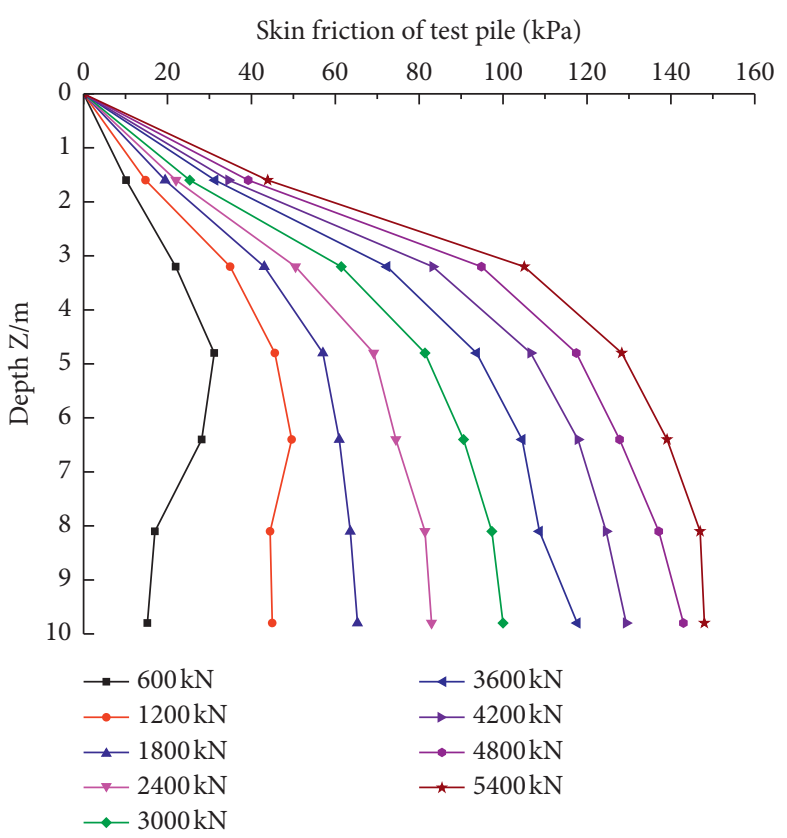

(b)

Skin friction of test pile $(\mathrm{kPa})$

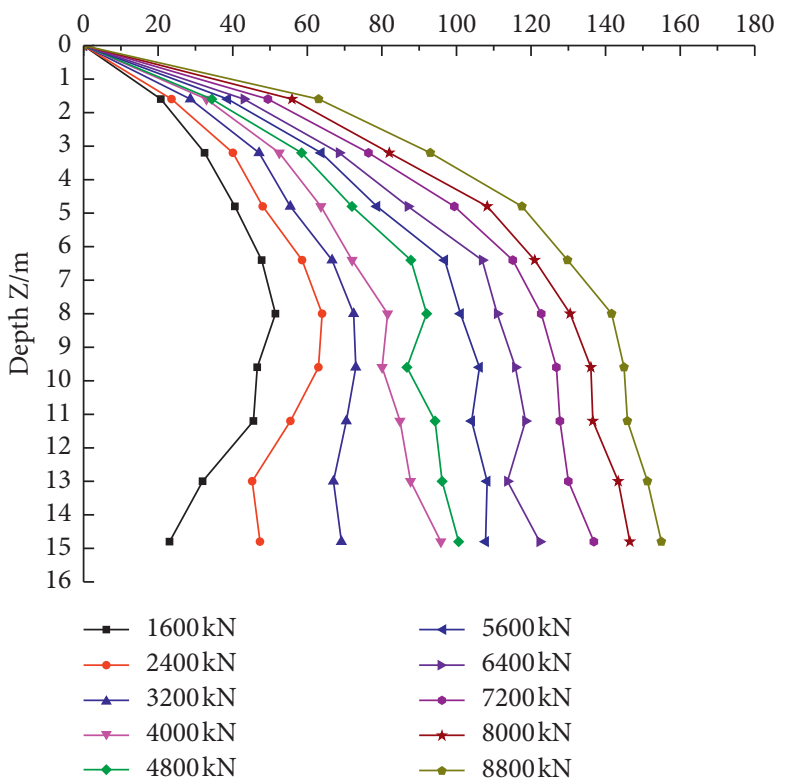

(d)

Figure 11: Distribution of shaft skin resistance on each pile. (a) No. 1 pile. (b) No. 2 pile. (c) No. 3 pile. (d) No. 4 pile.

TABLE 6: Value of shaft skin resistance of piles at different depths when reaching ultimate bearing capacity.

\begin{tabular}{|c|c|c|c|c|c|c|c|c|c|}
\hline \multicolumn{10}{|l|}{ (a) No. 1 pile } \\
\hline Depth $Z / \mathrm{m}$ & 1.7 & 3.4 & 5.1 & 6.8 & 8.5 & & & & \\
\hline Skin friction $/ \mathrm{kPa}$ & 60.177 & 112.974 & 133.037 & 139.158 & 135.235 & & & & \\
\hline \multicolumn{10}{|l|}{ (b) No. 2 pile } \\
\hline Depth $Z / \mathrm{m}$ & 1.6 & 3.2 & 4.8 & 6.4 & 8.1 & 9.8 & & & \\
\hline Skin friction $/ \mathrm{kPa}$ & 43.899 & 105.055 & 128.283 & 139.1 & 146.983 & 148.015 & & & \\
\hline \multicolumn{10}{|l|}{ (c) No. 3 pile } \\
\hline Depth $Z / \mathrm{m}$ & 1.6 & 3.2 & 4.8 & 6.4 & 8.1 & 9.8 & & & \\
\hline Skin friction $/ \mathrm{kPa}$ & 46.948 & 106.907 & 130.723 & 145.894 & 147.938 & 150.828 & & & \\
\hline \multicolumn{10}{|l|}{ (d) No. 4 pile } \\
\hline Depth $Z / \mathrm{m}$ & 1.6 & 3.2 & 4.8 & 6.4 & 8 & 9.6 & 11.2 & 13 & 14.8 \\
\hline Skin friction $/ \mathrm{kPa}$ & 63.055 & 93.009 & 117.592 & 129.804 & 141.642 & 144.953 & 145.865 & 151.216 & 154.956 \\
\hline
\end{tabular}




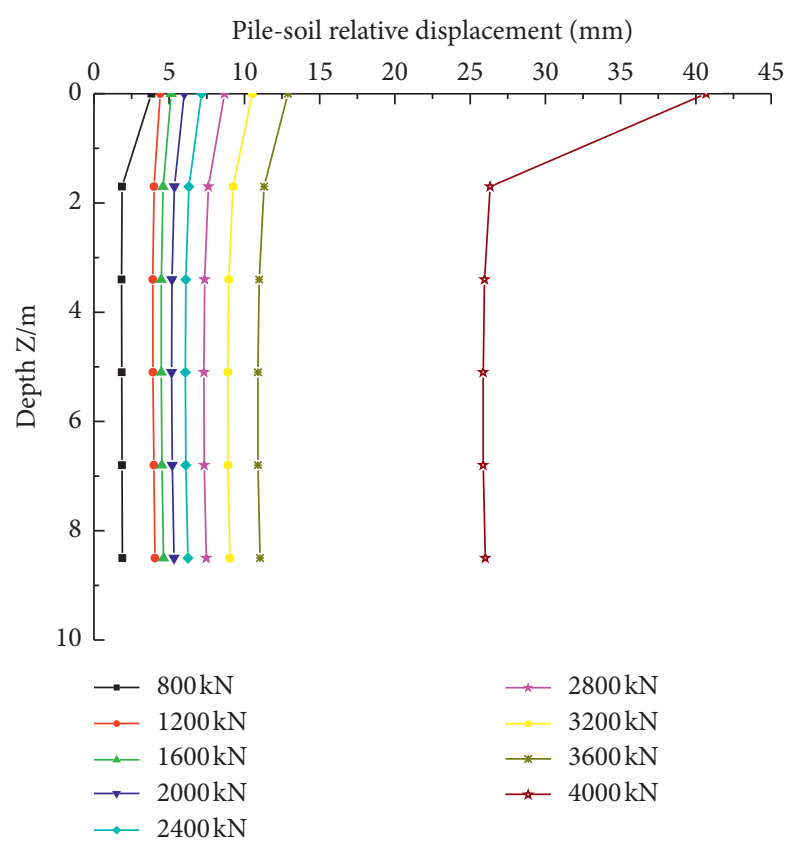

(a)

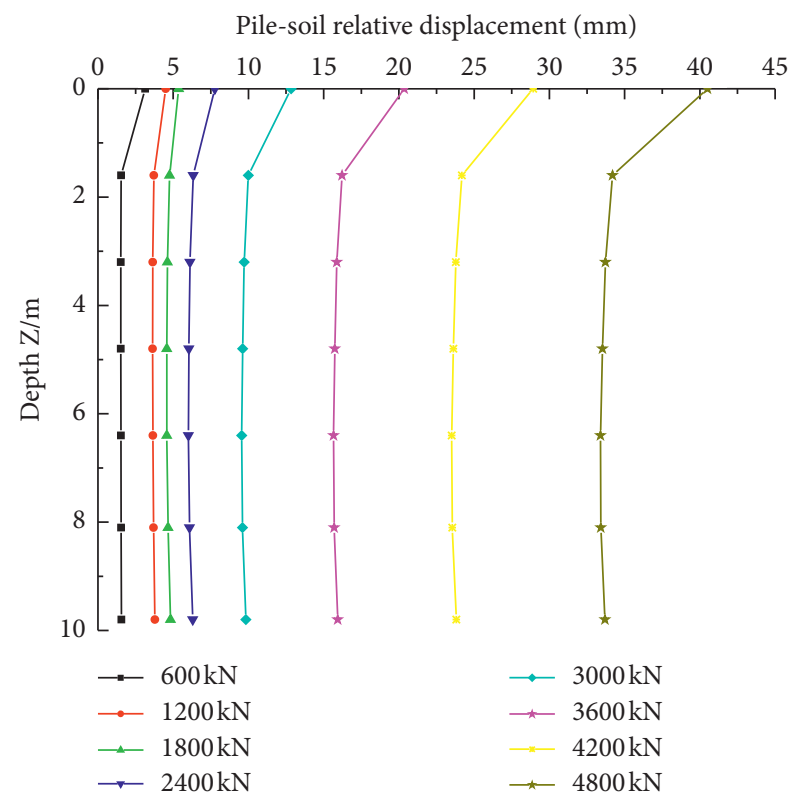

(c)

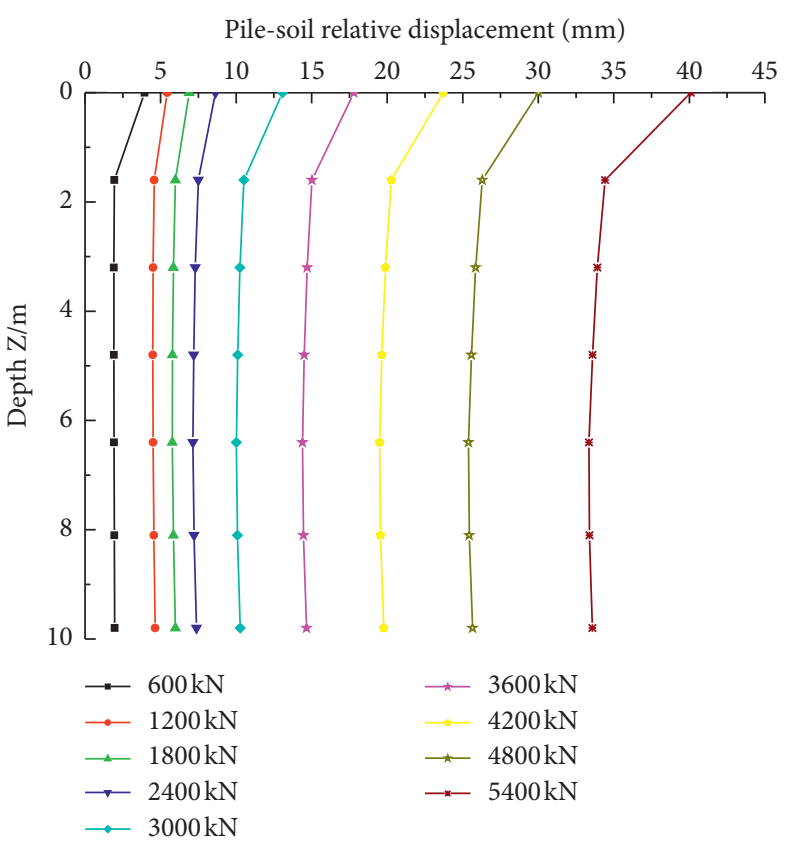

(b)

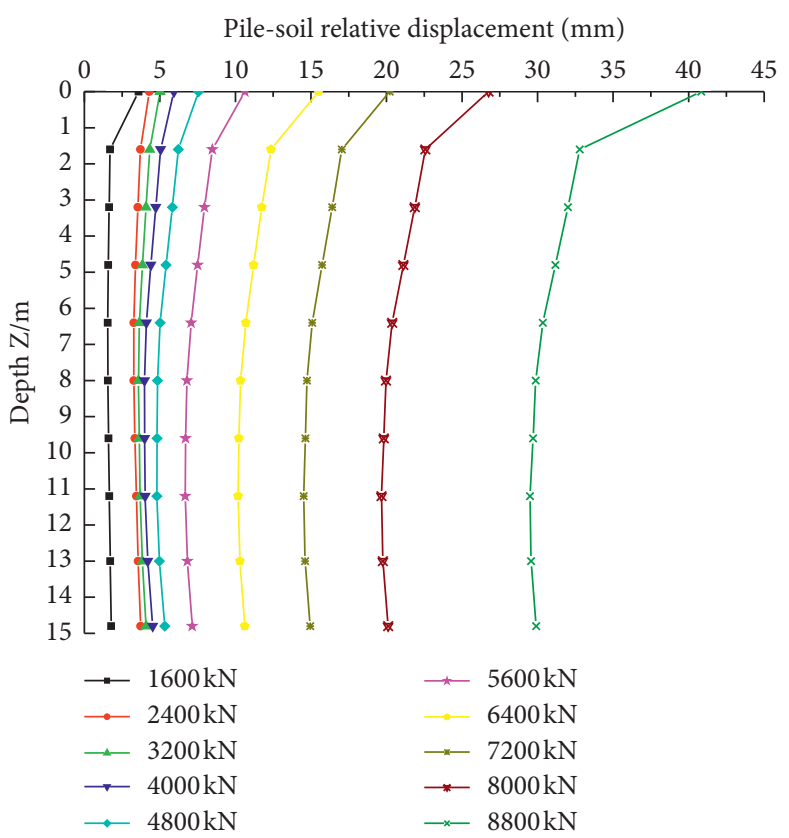

(d)

Figure 12: Pile-soil relative displacement curve. (a) No. 1 pile. (b) No. 2 pile. (c) No. 3 pile. (d) No. 4 pile.

resistance value can be calculated by the following formula according to the change value of the axial force of the pile body:

$$
q_{s i}=\frac{Q_{i}-Q_{i+1}}{u \cdot l_{i}}
$$

where $q_{s i}$ is the resistance between the $i$ section and the $i+1$ section; $i$ is the same as in formula (1); $u$ is the perimeter of pile body; $l_{i}$ is the pile length between the $i$ section and the $i+1$ section.
Figures 10(a)-10(d) show the distribution of shaft skin resistance of piles Nos. 1, 2, 3, and 4 with depth under different steps of loading.

As can be seen from Figure 11, in lower loading step, the shaft skin resistance of each pile is small; with the increase of loading steps, the shaft skin resistance of each pile increases. On the whole, the shaft skin resistance of the pile is also gradually transmitted from the upper part of the pile body to the lower part of the pile body, but, compared with the middle part of the pile body, the shaft skin resistance of the lower part of the first pile body with empty-bottom shows a 


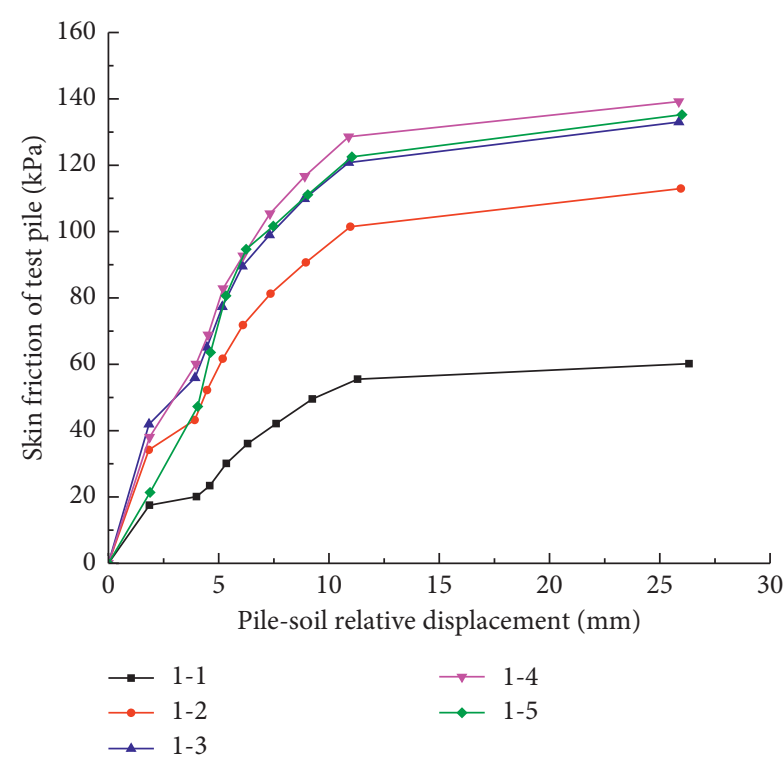

(a)

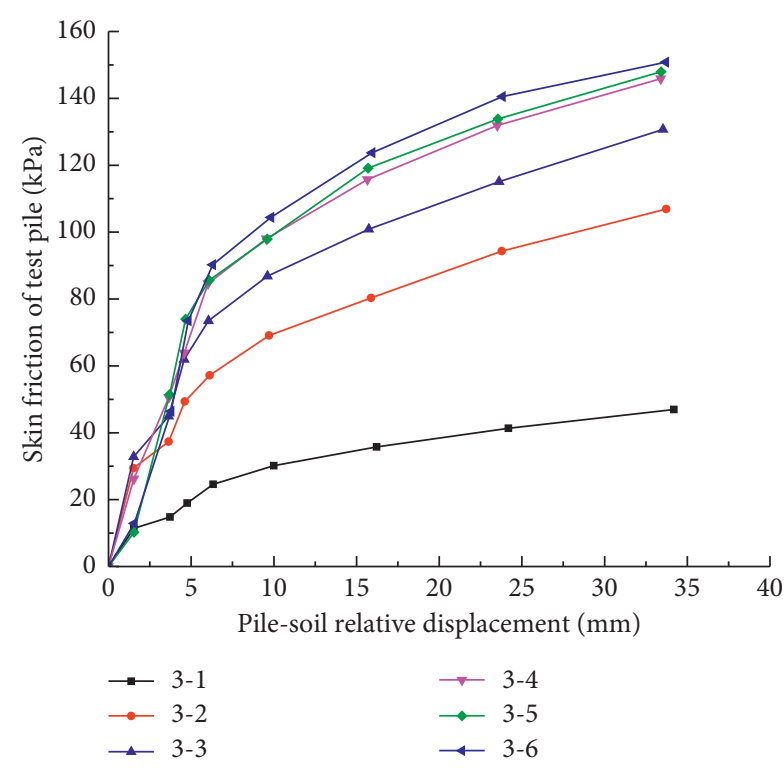

(c)

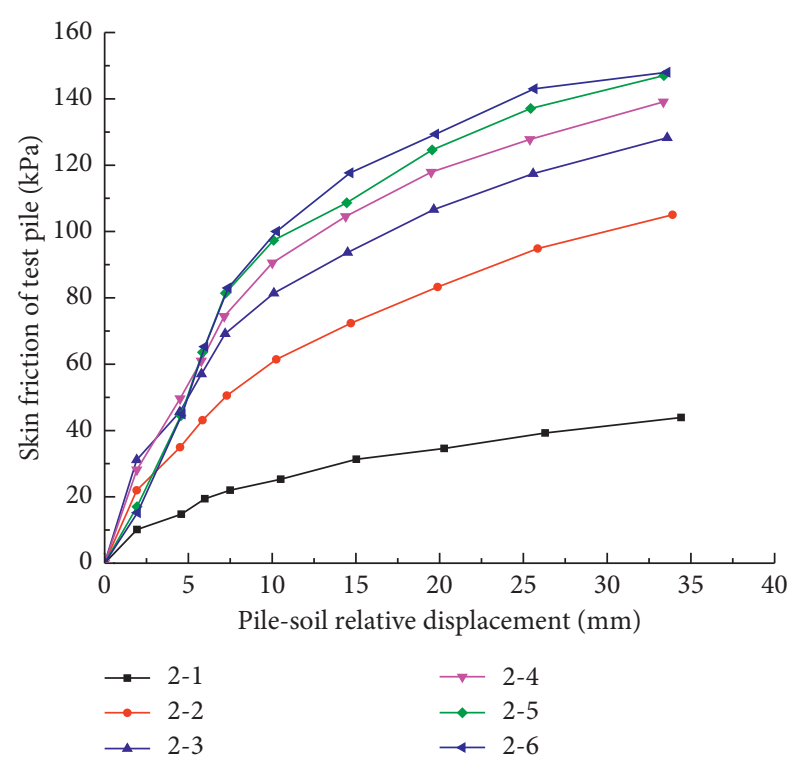

(b)

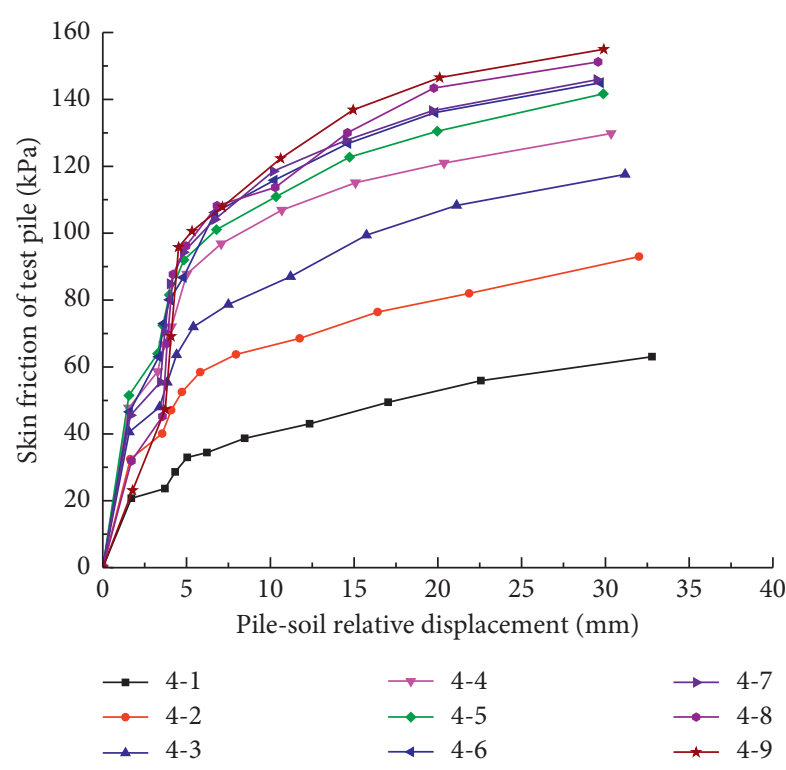

(d)

Figure 13: Distribution curves of shaft skin resistances versus relative displacements. (a) No. 1 pile. (b) No. 2 pile. (c) No. 3 pile. (d) No. 4 pile.

decreasing trend, because there is no soil bearing the corresponding load at the pile tip; however, for the remaining three solid-bottom piles, when the tip resistance is mobilized to a certain extent, the friction resistance in the middle part of the pile body is smaller than that in the lower part, which indicates that the soil at the pile tip can reinforce the shaft skin resistance of the pile [25]. When the ultimate bearing capacity is reached, the shaft skin resistance values of the corresponding piles at various depths are shown in Table 6 .

\subsection{Relationship between Shaft Skin Resistance and Pile-Soil} Relative Displacement. The pile-soil relative displacement objectively reflects the mobilization of shaft skin resistance.
According to the calculation method in [26], the pile-soil relative displacement curves under different loading steps are calculated and drawn. The curves of shaft skin resistance and pile-soil relative displacement are shown in Figures 12(a)-12(d), respectively.

In the calculation of the pile-soil relative displacement, it is assumed that the soil around the pile will be not displaced. As can be seen from Figure 12, the pile-soil relative displacement at the same position of the pile body increases with the increase of loading steps on the pile tip. When the first two steps of loading are applied, the pile-soil relative displacement of the four piles increases obviously due to the compaction effect of the first two steps of loading on the gravel soil around the pile. As the load level continues to increase, the pile-soil 
relative displacement increment is relatively small because the shaft skin resistance gradually mobilizes its function to prevent the pile from moving. With the increase of loading, when the shaft skin resistance cannot resist the load, at the loading sections $4800 \mathrm{kN}-5400 \mathrm{kN}, \quad 4200 \mathrm{kN}-4800 \mathrm{kN}$, $8000 \mathrm{kN}-8800 \mathrm{kN}$, and $3600 \mathrm{kN}-4000 \mathrm{kN}$, the maximum displacements of pile tips of Nos. 2, 3, and 4 solid-bottom pile and the empty-bottom pile increase by $9.792 \mathrm{~mm}, 7.939 \mathrm{~mm}$, $9.881 \mathrm{~mm}$, and $14.97 \mathrm{~mm}$, respectively.

The shaft skin resistance increases with the increase of pile-soil relative displacement. Although continuous loading has led to foundation soil destruction, it can be concluded from Figure 13 that the lateral resistance in the middle and lower parts is not fully mobilized, and a certain pile-soil relative displacement is needed to promote the full mobilization of the shaft skin resistance. However, according to the development trend that the slope of the shaft skin resistance gradually decreases, it can be inferred that the shaft skin resistance will reach the maximum value. At the first section position, the ultimate shaft skin resistance of piles Nos. 1, 2, 3, and 4 are $46.95 \mathrm{kPa}, 43.90 \mathrm{kPa}, 60.18 \mathrm{kPa}$, and $63.05 \mathrm{kPa}$ respectively, and the corresponding pile-soil relative displacements are $34.19 \mathrm{~mm}, 34.42 \mathrm{~mm}, 26.33 \mathrm{~mm}$, and $32.79 \mathrm{~mm}$. In the second section, the shaft skin resistance of the four piles increases greatly, so does the pile-soil relative displacement. Since the soil above the first section position is basically cultivated soil, and it can resist small shaft skin resistance, while the content of gravel soil of the second section is large, and, with the increase of depth, the surrounding pressure of soil around the pile increases, therefore the ability of resisting pile foundation sliding and displacement increases. Therefore, between the first section and the second section, the shaft skin resistance increases greatly, while the pile-soil relative displacement increases a little. In the second section and beyond, the soil is gravel soil, and the shaft skin resistance increases slightly with the increase of pile depth, and the relative displacement decreases gradually.

4.4. Pile Tip Resistance Varies with Load and Displacement. During the test, the section where the largest embedded depth of strain gauges is very close to the bottom of the pile was shown, so the resistance at the pile tip is approximately equal to the axial force measured at this section, namely, $Q_{b}=Q_{0}$. Under the action of all loading steps, the resistance variation curves at the lower tips of the Nos. 2, 3, and 4 piles are shown in Figure 14.

The No. 2 and No. 3 piles in the first two loading steps and No. 4 pile in the first loading step have smaller resistance at the pile tip. The resistance at the pile tip gradually increases until the third and fourth loading steps. Under the action of ultimate load, the ratio of pile tip resistance to pile top load of Nos. 2, 3, and 4 is $37.7 \%, 30.08 \%$, and $39.92 \%$, respectively, all higher $15 \%$, which shows that pile tip resistance has been brought into play to a certain extent. The pile tip resistance is shared by shaft skin resistance and pile tip resistance, and the pile is of tip bearing friction pile.

According to the relationship curve between pile tip resistance and pile tip displacement shown in Figure 15, it

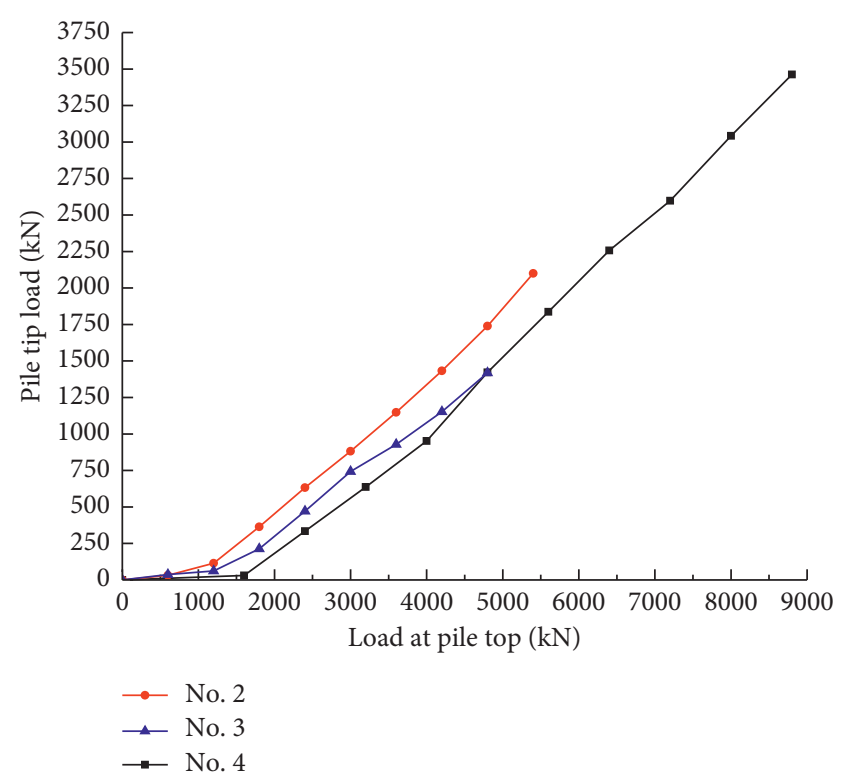

FIgURE 14: Variation curve of pile tip resistance under different loading steps. (a) No. 1 pile. (b) No. 2 pile. (c) No. 3 pile. (d) No. 4 pile.

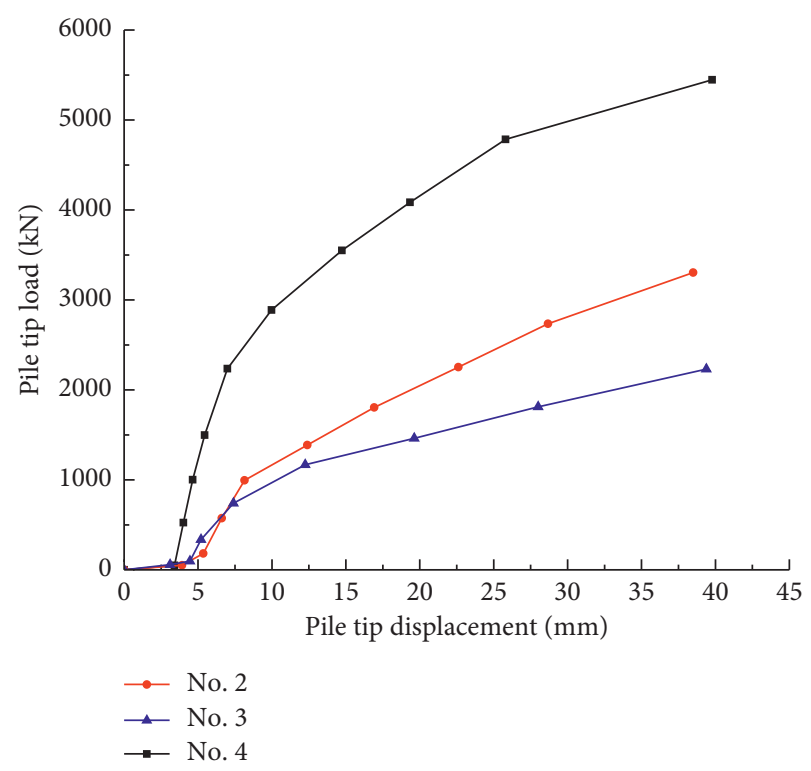

FIGURE 15: Relationship curve between pile tip resistance and pile tip displacement. (a) No. 1 pile. (b) No. 2 pile. (c) No. 3 pile. (d) No. 4 pile.

can be seen that the pile tip resistance and pile tip displacement present a double fold line model of work hardening. The Nos. 2, 3, and 4 piles all show a slow deformation failure, and, under the action of the first loading step, the slope of the curve is larger, and the corresponding displacement is relatively small; in latter steps of loading, the curvature curve becomes smoother, the displacement of the pile tips of adjacent loads increases, and the soil at the pile tips will gradually be compacted. 


\section{Conclusions}

Analyses are carried out on data of the in-situ test of uneven gravel soil in Baishi Mountain, and the following conclusions are drawn:

(1) Based on the analysis of the results of multichannel transient surface wave test, superheavy $\left(\mathrm{N}_{120}\right)$ cone dynamic sounding test, and on-site screening test, the geological environment conditions of the uneven gravel soil on the site are further explored. The strata within the range from 0 to $15 \mathrm{~m}$ in Baizhi Mountain can be divided into four layers, i.e., cultivated soil, sandy soil, silty clay, and gravel soil, with depths of $1 \mathrm{~m}, 2 \mathrm{~m}, 3 \mathrm{~m}$, and $9 \mathrm{~m}$, respectively.

(2) The axial force and shaft skin resistance of pile body in gravel soil are the same as those in other geological structures. At the initial loading step, the axial force and shaft skin resistance of pile body play a smaller role. With the increase of loading steps, the axial force and shaft skin resistance of pile body increase correspondingly. Under the same loading step, the axial force of the pile body and the shaft skin resistance do not mobilize in the same time and gradually transfer from the upper part to the lower part of the pile body, and the upper part of the pile body reaches the limit value before the middle and lower parts. As for the solid-bottom pile, the soil at the pile tip will strengthen the shaft skin resistance of the pile.

(3) According to this experimental study, it is suggested that similar projects should adopt concrete manually bored cast-in-place piles with a diameter of $900 \mathrm{~mm}$ and a length of $15 \mathrm{~m}$, the wall-protecting thickness shall not be less than $175 \mathrm{~mm}$, and the grade of concrete cannot be lower than C35. The pile end can be widened or not, and the pile bottom shall be free of sediment.

\section{Data Availability}

All the data in this paper are obtained from tests in this study, and no other data were used to support this study.

\section{Conflicts of Interest}

The authors declare that, with regard to the publication of this paper and the funding for publishing it, there are no conflicts of interest.

\section{Acknowledgments}

This study was partially supported by the National Natural Science Foundation of China (Grant no. 41302223), Chongqing No. 3 colleges and universities youth backbone teachers funding plans, Chongqing Research Program of Basic Research and Frontier Technology (Grant no. cstc2016jcyjA0074, cstc2016jcyjA0933, and cstc2015jcyjA90012), Scientific and Technological Research Program of Chongqing Municipal
Education Commission (Grant no. KJ1713327 and KJ1600532), Key Laboratory of Well Stability and Fluid and Rock Mechanics in Oil and Gas Reservoir of Shaanxi Province, Xi'an Shiyou University (Grant no. FRM20190201002), Chongqing Postgraduate Research Innovation Project (Grant no. CYS19353), and Chongqing University of Science and Technology Graduate Students' Science and Technology Innovation Program (Grant no. YKJCX1720601 and YKJCX1920613).

\section{References}

[1] F. Kirsch and B. Plabmann, "Dynamic methods in pile testing: developments in measurement and analysis," in Proceedings of the International Deep Foundations Congress 2002, pp. 868882, ASCE, Orlando, FL, USA, February 2002.

[2] S. H. Ni, L. Lehmann, J. J. Charng et al., "Low-strain integrity testing of drilled piles with high slenderness ratio," Computers and Geotechnics, vol. 33, no. 6-7, pp. 283-293, 2006.

[3] K. Mori, A. Spagnoli, Y. Murakami, G. Kondo, and I. Torigoe, "A new non-contacting non-destructive testing method for defect detection in concrete," NDT \& E International, vol. 35, no. 6, pp. 399-406, 2002.

[4] G. Cai, S. Liu, L. Tong et al., "Assessment of direct CPT and CPTU methods for predicting the ultimate bearing capacity of single piles," Engineering Geology, vol. 104, no. 3-4, pp. 211-222, 2009.

[5] X. Y. Bai, M. Y. Zhang, L. Zhu et al., "In-situ test and finite element analysis of bearing characteristics of rock-socketed short piles in strongly weathered granite," Journal of Central South University: Natural Science Edition, vol. 48, no. 2, pp. 512-524, 2017, in Chinese.

[6] E. C. Leong and M. F. Randolph, "Finite element modelling of rock-socketed piles," International Journal for Numerical and Analytical Methods in Geomechanics, vol. 18, no. 1, pp. 25-47, 1994.

[7] G. Gao, M. Gao, Q. Chen, and J. Yang, "Field load testing study of vertical bearing behavior of a large diameter belled cast-in-place pile," KSCE Journal of Civil Engineering, vol. 23, no. 5, pp. 2009-2016, 2019.

[8] R. Berardi and R. Bovolenta, "Pile-settlement evaluation using field stiffness non-linearity," Proceedings of the Institution of Civil Engineers - Geotechnical Engineering, vol. 158, no. 1, pp. 35-44, 2005.

[9] B. H. Fellenius, Basics of Foundation Design, Lulu Press, Morrisville, NC, USA, 2016.

[10] C. Lam and S. A. Jefferis, "Critical assessment of pile modulus determination methods," Canadian Geotechnical Journal, vol. 48, no. 10, pp. 1433-1448, 2011.

[11] A. Mohammadi, T. Ebadi, and M. R. Boroomand, "Physical modelling of axial compressive bearing capacity of instrumented piles in oil-contaminated sandy soil," Iranian Journal of Science and Technology, Transactions of Civil Engineering, vol. 44, no. 2, pp. 695-714, 2019.

[12] W. D. Guo and E. H. Ghee, "Behavior of axially loaded pile groups subjected to lateral soil movement," in Proceedings of the GeoShanghai International Conference 2006, pp. 174-181, ASCE, Shanghai, China, June 2006.

[13] Z. Zhou, Y. Dong, P. Jiang, D. Han, and T. Liu, "Calculation of pile side friction by multiparameter statistical analysis," Advances in Civil Engineering, vol. 2019, Article ID 2638520, 12 pages, 2019. 
[14] N. M. Hai and B. H. Fellenius, "O-Cell tests on two $70 \mathrm{~m}$ long bored piles in Vietnam," in Proceedings of the Geo-Congress 2014, pp. 482-496, ASCE, Atlanta, Georgia, February 2014.

[15] S. Gong, G. Cai, S. Liu et al., "Numerical Simulation of Bearing Capacity and Consolidation Characteristics of PHC Pile Foundation". GeoShanghai International Conference, pp. 178-185, Springer, Singapore, 2018.

[16] M. A. Bashir, H. Furuuchi, T. Ueda, and M. Nauman Bashir, "Numerical simulation of axial anchorage capacity of concrete-filled steel box footing," Iranian Journal of Science and Technology, Transactions of Civil Engineering, vol. 40, no. 3, pp. 257-262, 2016.

[17] N. A. Haskell, "The dispersion of surface waves on multilayered media," Bulletin of the Seismological Society of America, vol. 43, no. 1, pp. 17-34, 1953.

[18] China Architecture \& Building Press, National Standard of the People's Republic of China, Code for Investigation of Geotechnical Engineering (GB50021 2016), China Architecture \& Building Press, Beijing, China, 2016, in Chinese.

[19] China Architecture \& Building Press, Industry Standard of the People's Republic of China, Technical Code for Testing of Building Foundation Piles (JGJ106-2014), China Architecture \& Building Press, Beijing, China, 2014, in Chinese.

[20] N. Guo, Z. H. Chen, X. F. Huang et al., "Research on the antipulling test of large-diameter cloth bag pile in soft rock foundation," Rock and Soil Mechanics, vol. 36, no. 2, pp. 603-609, 2015, in Chinese.

[21] Y. H. Li, X. Zhu, and T. H. Zhou, "Field comparative experimental study on the influence of post-tip grouting on large-diameter cast-in-situ piles," Rock and Soil Mechanics, vol. 37, no. 2, pp. 388-396, 2016, in Chinese.

[22] G. F. Xin, Z. M. Zhang, T. Xia et al., "Experimental study on bearing behavior of ultra-long pile under high load," Chinese Journal of Rock Mechanics and Engineering, vol. 13, pp. 2397-2402, 2005, in Chinese.

[23] Z. Ling, W. Wang, J. Wu et al., "Full-scale loading test on prebored precast pile with enlarged base in Shanghai," in Proceedings of the GeoShanghai 2018 International Conference: Advances in Soil Dynamics and Foundation Engineering, pp. 637-645, Springer, Singapore, 2018.

[24] J. R. Dong, S. T. Lin, and Y. M. Dai, “The load tranfer behavior of large diameter cast-in-situ pile in crushed pebble stratum," Chinese Journal of Geotechnical Engineering, vol. 16, no. 6, pp. 123-131, 1994.

[25] X. F. Huang, J. H. Zhang, L. G. Ma et al., "Experimental study on reinforcement effect of lateral resistance of collapsible loess rock-socketed perfusion pile," Architectural Structure, vol. 41, no. 2, pp. 351-355, 2011, in Chinese.

[26] J.-J. Zhou, K.-H. Wang, X.-N. Gong, and R.-H. Zhang, "Bearing capacity and load transfer mechanism of a static drill rooted nodular pile in soft soil areas," Journal of Zhejiang University Science A, vol. 14, no. 10, pp. 705-719, 2013. 